\title{
EXPERIMENTS IN NATURE AND LABORATORY OBSERVATIONS WITH NAUSITHOE AUREA (SCYPHOZOA: CORONATAE) SUPPORT THE CONCEPT OF PERENNATION BY TISSUE SAVING AND CON- FIRM DORMANCY
}

\author{
Fábio Lang da Silveira ${ }^{1}$ (correspondence author; correspondência para), Gerhard Jarms ${ }^{2}$ \& André Carrara \\ Morandini $^{1}$
}

Biota Neotropica v2 (n2) - http://www.biotaneotropica.org.br/v2n2/pt/abstract?article+BN02202022002

\author{
Date Received 07/19/2002 \\ Revised 09/23/2002 \\ Accepted 10/02/2002
}
${ }^{1}$ Departamento de Zoologia, Instituto de Biociências, Universidade de São Paulo, Caixa Postal 11461, 05422-970, São Paulo, SP, Brasil.
Tel.:+55-11-30917619Fax: +55-11-30917513
${ }^{2}$ Zoologisches Institut und Zoologisches Museum, Universität Hamburg, Martin-Luther-King Platz 3, 20146 Hamburg, Germany,
Tel.: +49-40-428382086 Fax:+49-40-428382086
e-mails: fldsilve@usp.br, Gerhard.Jarms@zoologie.uni-hamburg.de, acmorand@usp.br

\begin{abstract}
Stephanocyphistomae of Nausithoe aurea from São Paulo State, Brazil (in subtropical western South Atlantic waters), were relocated with their substrata in nature to study their survivorship under control and and experimental series i.e. the polyps in the original orientation and inverted, and in each series exposed and buried polyps. We found that $N$. aurea survives over 13 months in nature, between 1/3 - 1/4 of 268 stephanoscyphistomae as normal feeding polyps, by segmentation produces planuloids and rejuvenates the polyps — an additional explanation for clustering of the solitary stephanocyphistomae. Dormant living tissues within the periderm of the tube were considered resting stages. The results support the concept that coronates in general have the capacity to save all living tissue and transform it to the energy saving sessile stage — the perennial polyp.

Key-words: Cnidaria, Scyphozoa, Nausithoe aurea, perennation, resting stages, Brazil.

\section{Resumo}

Estefanocifístomas de Nausithoe aurea no Estado de São Paulo, Brasil (em águas subtropicais do Atlântico Sul ocidental), foram realocados com os seus substratos na natureza para estudar a sobrevivência em séries controle e experimental - isto é, os pólipos na posição original e invertidos e em cada série pólipos expostos e enterrados. Verificamos que N. aurea sobrevive por 13 meses na natureza, entre 1/3 - 1/4 de 268 estefanocifístomas como pólipos normais capazes de alimentação, por segmentação produz planulóides e rejuvenesce o pólipo — uma explicação adicional para a ocorrência agregada dos estefanocifístomas solitários. Tecidos vivos dormentes dentro da periderme do tubo foram considerados como estágios de quietação. Os resultados reforçam a idéia de que os coronados em geral têm a capacidade de conservar todo o tecido vivo e de transformá-lo durante o estágio séssil mais econômico energeticamente - o pólipo perene.
\end{abstract}

Palavras-chave: Cnidaria, Scyphozoa, Nausithoe aurea, perenização, estágios de quietação, Brasil. 


\section{Introduction}

At present the life cycles of 16 species of Coronatae are known, the variations range from typical metagenesis by strobilation (polyp > strobilation $>$ detached ephyrae $>$ adult medusae $>$ planulae) to the suppression of the stephanoscyphistomae or the medusae. These life cycles are:

- complete metagenesis: Atorella japonica (see Kawaguti \& Matsuno, 1981), Atorella vanhoeffeni (see Werner, 1966), Nausithoe hagenbecki (see Jarms, 2001), Nausithoe punctata (see Werner, 1973) and Nausithoe werneri (see Jarms, 1990);

- complete metagenesis combined with abbreviated metagenesis and/or 'segmentation': Nausithoe aurea (see Silveira \& Morandini, 1997) Linuche unguiculata (see Silveira \& Morandini 1998a);

- metagenesis combined with abbreviated life cycle ('tissue balls'): Nausithoe globifera, Nausithoe maculata, Nausithoe marginata, and Nausithoe thieli (Jarms 1997);

- reduced metagenesis (medusoids): Nausithoe eumedusoides (see Werner, 1974) and Nausithoe racemosa (see Komai, 1936);

- reduced metagenesis (planuloids): Nausithoe planulophora (see Werner, 1971);

- without metagenesis (without polyps and planulae): Periphylla periphylla (see Jarms et al., 1999);

- without metagenesis (parthenogenesis): Thecoscyphus zibrowii (see Sötje \& Jarms, 1999).

Morandini (1999) and Morandini \& Silveira (2001a) reviewed the history of knowledge about stephanoscyphistomae of Coronatae in Brazil. Morandini \& Silveira (2001a) complemented the diagnostic features for Nausithoe aurea Silveira \& Morandini, 1997, and showed that the species occurs north of its type locality in Brazil, and Morandini \& Silveira (2001b) described the gametogenesis of the species. Jarms et al. (2002) studied preserved deep-water polyps of the families Atorellidae and Nausithoidae from the Brazilian coast. Furthermore, Silveira \& Morandini (1998a and b) have described segmentation and dormancy sensu Cáceres (1997: 372), i.e. the occurrence of resting stages, in the species Linuche unguiculata (Swartz, 1788).

The present study on the survivorship of Nausithoe aurea in nature, under control and experimental relocate circumstances, was undertaken over a 13 months period. Observations were based on just sampled material from the relocation site in southeast Brazil and following cultures of the stephanoscyphistomae. We wanted to know how $N$. aurea survives under unstable conditions and and whether the flexibility in its life cycle and whether the flexibility in its life cycle might be an advantage (or adaptation) for living in a frequently changing environment.

\section{Material and Methods}

To initiate our study, on July 18, 2000, seven fragments of dead stony coral Mussismilia hispida (Verrill, 1902) (Scleractinia, Mussidae) were sampled at 2-6 m depth by SCUBA diving, in the São Sebastião Channel (2350'S $\left.-45^{\circ} 25^{\prime} \mathrm{W}\right)$, on Praia Grande reef, Ilhabela County, SP. We searched for the polyps on the calcareous substrata with the aid of a stereomicroscope at Centro de Biologia Marinha da Universidade de São Paulo (CEBIMar USP). Two sets of Nausithoe aurea, each with six stephanoscyphistomae, were obtained from the exposed surface and from the buried surface of two calcareous debris. They were transferred into and maintained in cell culture dishes $(60 \mathrm{~mm} \mathrm{x}$ $15 \mathrm{~mm}$ ) containing about $100 \mathrm{ml}$ of filtered seawater. We had made the first cultivation under controlled room temperature, $21.0^{\circ} \mathrm{C}$, from July 19 to 27,2000 at CEBIMar. On July 27 the specimens were transferred, each in a small airtight flask (70 $\mathrm{ml})$ and air-conditioned car, to the Zoology Department (IB USP), in São Paulo, SP, and reared inside an incubator (FANEM@ $347-C D G)$ at $22 \pm 1{ }^{\circ} \mathrm{C}(6 / 18$ hours light/dark) until August 7. After the third day of examinations, at two day intervals, a few recently hatched nauplii (24-48 hours) of Artemia sp. were added to the culture dishes for a period of 24 hours. The filtered seawater in the culture dishes - provided by CEBIMar USP and stored inside a dark incubator at $22 \pm 1{ }^{\circ} \mathrm{C}$, was changed every day. By day ten of the observations, gentle rubbing with a delicate brush cleaned each polyp.

From the same reef, at Ilhabela, July 19, 2000, fiftyeight fragments of dead stony coral $M$. hispida were sampled at 2-6 m depth by SCUBA diving. The calcareous debris were stored in large tanks with running seawater. In the laboratory of CEBIMar USP, we searched for the stephanoscyphistomae, with the aid of a stereomicroscope, on the exposedJuly 19, 2000, as well as on the buried surfaces of the calcareous substratum, to find at least six polyps of $N$. aurea. By July 24, 2000, we had set aside forty-eight fragments of dead stony coral (always $M$. hispida). A long screw $(15 \mathrm{~cm})$ (Fig. 1) was applied to each calcareous segment. On July 25 to 27, 2000, the fragments were transplanted to the field at the base of a high and nearly vertical rockwall at Jarobá Point (2349'39.6' S - 45 25'20'” W), 6 m depth, by SCUBA diving (a site within the protected rocky coast of CEBIMar). Two contiguous rows of twenty-four calcareous fragments each were laid on the sand bottom - the "experimental" and the "control" series. The control series was: the surfaces of twenty four fragments, respectively, twelve exposed and twelve buried, were laid to maintain their original position. The experimental series was: the surfaces of twenty four fragments, respectively, twelve exposed and twelve buried, were laid inverted. The initial set of twelve exposed and buried stephanoscyphistomae we considered to pertain to the controls. 


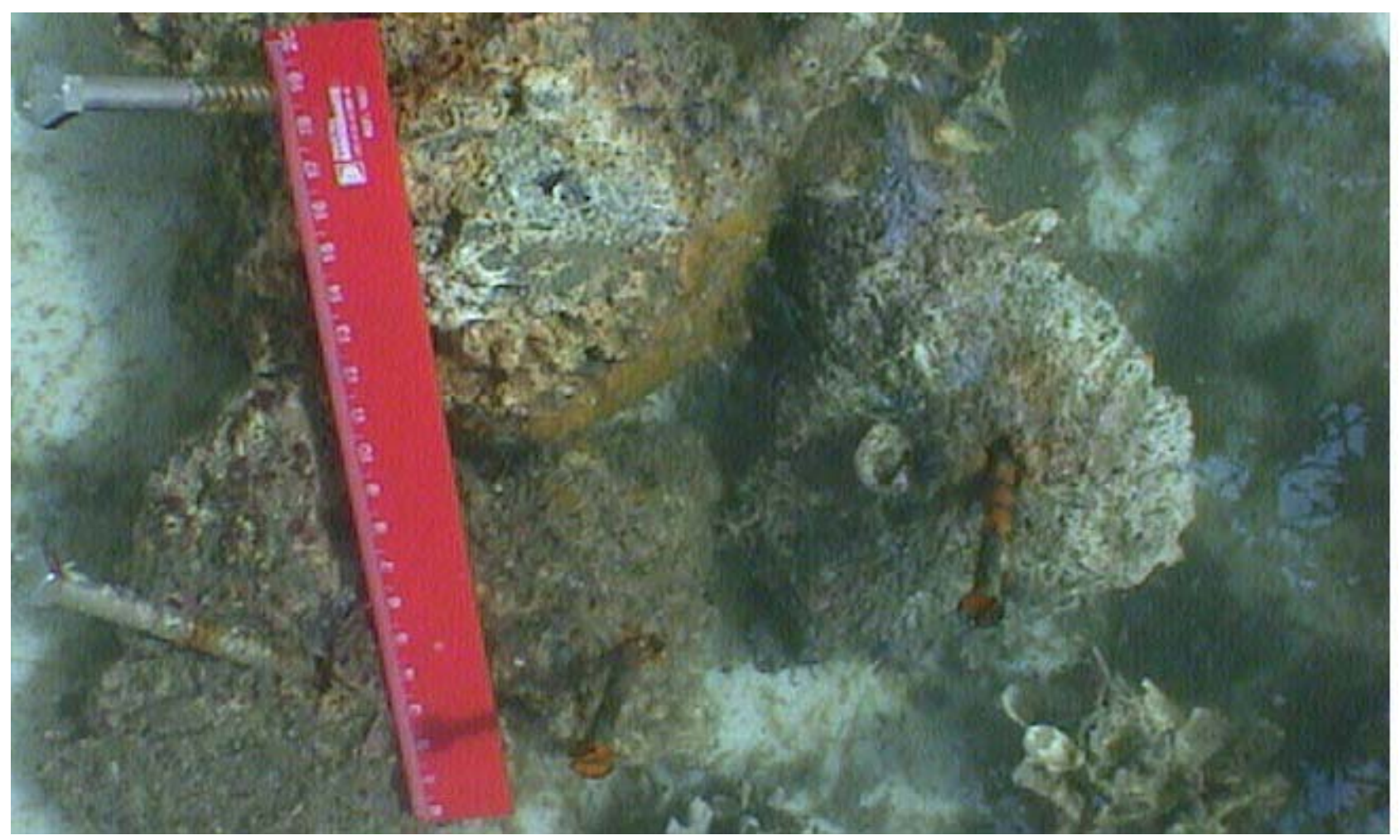

Figure 1. Photography (26.X.2000, at CEBIMar USP) of four calcareous fragments just sampled from Jarobá Point and to each fragment a long screw had been applied as a mark (Ruler: $20 \mathrm{~cm})$.

\begin{tabular}{|c|c|c|}
\hline $\mathbf{A}$ & B & $\mathrm{C}$ \\
\hline $\begin{array}{c}18 / N \Pi / 2000 \text { (initial } \\
\text { observations) }\end{array}$ & 20 & $18.8^{\circ} \mathrm{C}$ \\
\hline 24/VII/2000 & 20 & $18.3^{\circ} \mathrm{C}$ \\
\hline $25 / \mathrm{TX} / 2000$ & 20 & $19.1^{\circ} \mathrm{C}$ \\
\hline $26 / \mathrm{X} / 2000$ & 15 & $20.6^{\circ} \mathrm{C}$ \\
\hline $12 / \mathrm{XV} / 2000$ & 20 & $21.3^{\circ} \mathrm{C}$ \\
\hline $18 / \mathrm{XI} / 2000$ & 20 & $22.0^{\circ} \mathrm{C}$ \\
\hline $22 / \mathrm{J} 2001$ & 15 & $25.0^{\circ} \mathrm{C}$ \\
\hline $22 / \mathrm{TL} / 2001$ & $20^{*}$ & $25.7^{\circ} \mathrm{C}$ \\
\hline $29 /$ [I/2001 & 20 & $23.7^{\circ} \mathrm{C}$ \\
\hline $02 / \mathrm{V} / 2001$ & 20 & \multirow[t]{2}{*}{$23.9^{\circ} \mathrm{C}$} \\
\hline $27 / V / 2001$ & 15 & \\
\hline $02 / \mathrm{VII} / 2001$ & 20 & $20.7^{\circ} \mathrm{C}$ \\
\hline
\end{tabular}

*We had observed the modifications of one exposed polyp, in the control series, for 33 days.

Table 1. Dates in which (A) calcareous fragments with stephanoscyphistomae of Nausithoe aurea were retrieved from the sea and (B) days of observations in the laboratory; (C) monthly average of surface water temperature at CEBIMar. Note: average of surface water temperature for June and Julv $200 \mathrm{~J}$ was respectivelv. 20.4 and $19.5{ }^{\circ} \mathrm{C}$. 
Almost at monthly intervals, over thirteen months and by SCUBA diving, four transplanted coral fragments (two controls and two experiments, respectively, one exposed and one buried from each series), were retrieved from the sea, submersed in a large tank, gently washed with a constant flow of sea-water to remove the excess of sand so as to facilitate the finding of the polyps, twenty four stephanoscyphistomae were isolated in the laboratory. The polyps were kept, either in CEBIMar for the first five days (except for February 2001 with longer stay at CEBIMar), transferred to Zoology Department (as mentioned above) and observed for 15 - 20 days (Table 1).

\section{Results}

In this work we observed a total number of 268 stephanoscyphistomae, 141 and 127, respectively, from the control and experimental series. The following aspects were observed: (a) presence of particles closing the periderm tube; (b) particles pushed out of the periderm tube by the scyphistoma; (c) contracted living tissues within the periderm tube, but not contracting further upon gentle squeezing with delicate forceps; (d) contracted living tissues within the periderm tube, but still contracting further upon gentle squeezing with delicate forceps; (e) contracted living tissues within the periderm tube, but oral disk with recognizable tentacles; (f) expanded polyp and oral disc with $\boldsymbol{n}$ tentacles; (g) polyp with a simple column, i.e. without mesenteries or oral disc and tentacles; (h) polyp column with mesenteries, but without oral disc and tentacles; (i) strobilation and closed periderm operculum; (j) ephyrae; (k) half opened operculum; (l) removed operculum; (m) segmentation sensu Silveira \& Morandini (1998a); (n) planuloids (originated by strobilation or segmentation) within the periderm tube; (o) planuloid inside the polyp column; (p) free planuloids (see Plate I).

The majority of the stephanoscyphistomae did not present any perceptible amount of zooxanthellae, except for the finding of 4 polyps with much zooxanthellae in the gastrodermis ( 2 polyps from the exposed-control different series and 2 polyps from the exposed and buried-experimental single series). Two calcareous substrata retrieved from the sea on March 29, 2001, showed, on one, the overgrowth by the sponge Cliona aff. dioryssa De Laubenfels, 1950 and on the other the growth of coralline incrusting algae responsible for the absence of 3 and 5 stephanoscyphistomae, respectively, for the buried-control and exposed-experimental series. Two polyps died during our observations: one in the buried-experimental series from the sample on January 22, 2001, due to a large injury at the periderm pedal disk, at day 10 of cultivation; one in the buried-control series from the sample February 22,2001 , attacked by an unidentified ciliate protist (fast multiplying within the periderm tube), at day 8 of cultivation.

Apart from expected observations we could obtain with traditional rearing experiments in the laboratory,for Nausithoe aurea we found some different aspects as a) the rejection mechanism of particles within the periderm tube, b) segmentation and c) dormancy. During the rejection of particles within the periderm tube the stephanoscyphistoma pushed it by stretching column, this requiring that part of the particles (when there were plenty) or all (when there are few) be ingested by the distal region of the column and later spit out through the tube aperture. Segmentation was usually with the production of a periderm operculum and rarely under a plug of particles in the tube aperture, as Silveira \& Morandini (1998a) had described for the colonial coronate Linuche unguiculata. Often after segmentation, part of the resulting planuloids remained inside the gastrovascular cavity of the regenerating stephanoscyphistoma and, either left the polyp, with the opening of the operculum, or were resorbed (Figs 2 and 3). Segmentation may perhaps occur by an initial transverse fission halfway along the column of a normal polyp, and the closing of the tube with an operculum (Fig. 4). After segmentation, with the opening of the operculum the residual tissues under it, and not in the form of planuloids, are ingested by the stephanoscyphistoma (Fig. 5). We recognized dormancy as an undifferentiated polyp column, which could stay inside a blocked tube over a longer period.

For a summary analysis of our results, in terms of a general picture of the aspects related to the closing of the periderm tube, either by particles (mainly sand grains), by an operculum or particles + operculum, we combined all data in Table 2 for the control series and in Table 3 for the experimental series. In these tables we grouped our observations considering: a) the expected (= known) aspects of the biology of $N$. aurea, i.e. strobilation producing detached ephyrae or planuloids and/or regeneration of a normal feeding polyp (sensu Silveira \& Morandini, 1997: 242, Tab. VI; $237 ; 244)$; b) the different (= novel) aspects of the biology of $N$. aurea, i.e. a segmentation or dormancy mechanism as observed for the colonial L. unguiculata (sensu Silveira \& Morandini, 1998a and b). In the tables we note whether the results refer to the exposed or buried stephanoscyphistomae.

The occurrence of an oral disc and mesenteries was observed in $37(26.24 \%)$ and 31 (32.3\%) stephanoscyphistomae just sampled and during cultivation, respectively, from the control and experimental series. 


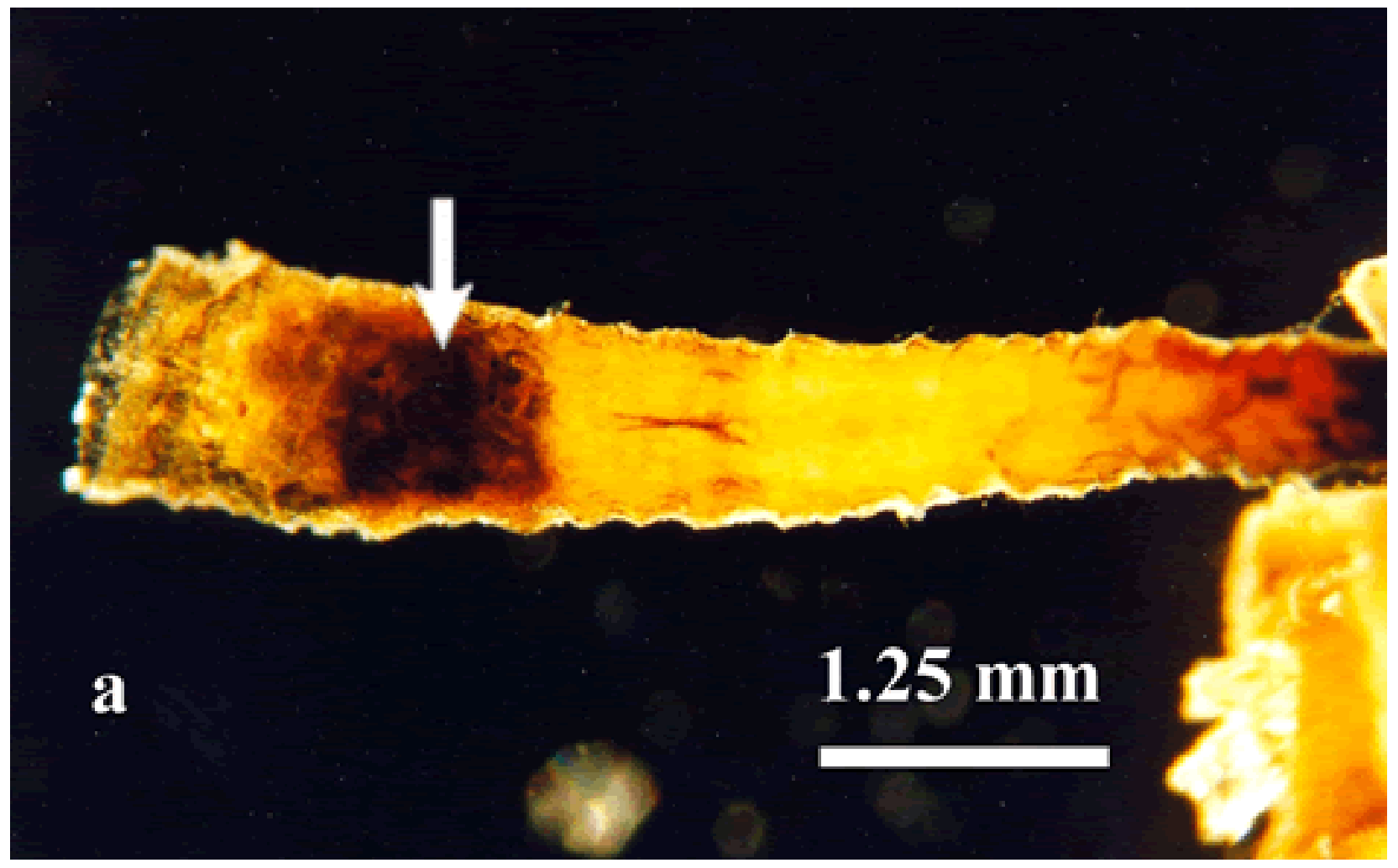

Plate I. Observed aspects of individual stephanoschyphistomae: (a) presence of particles closing the periderm tube (arrow);

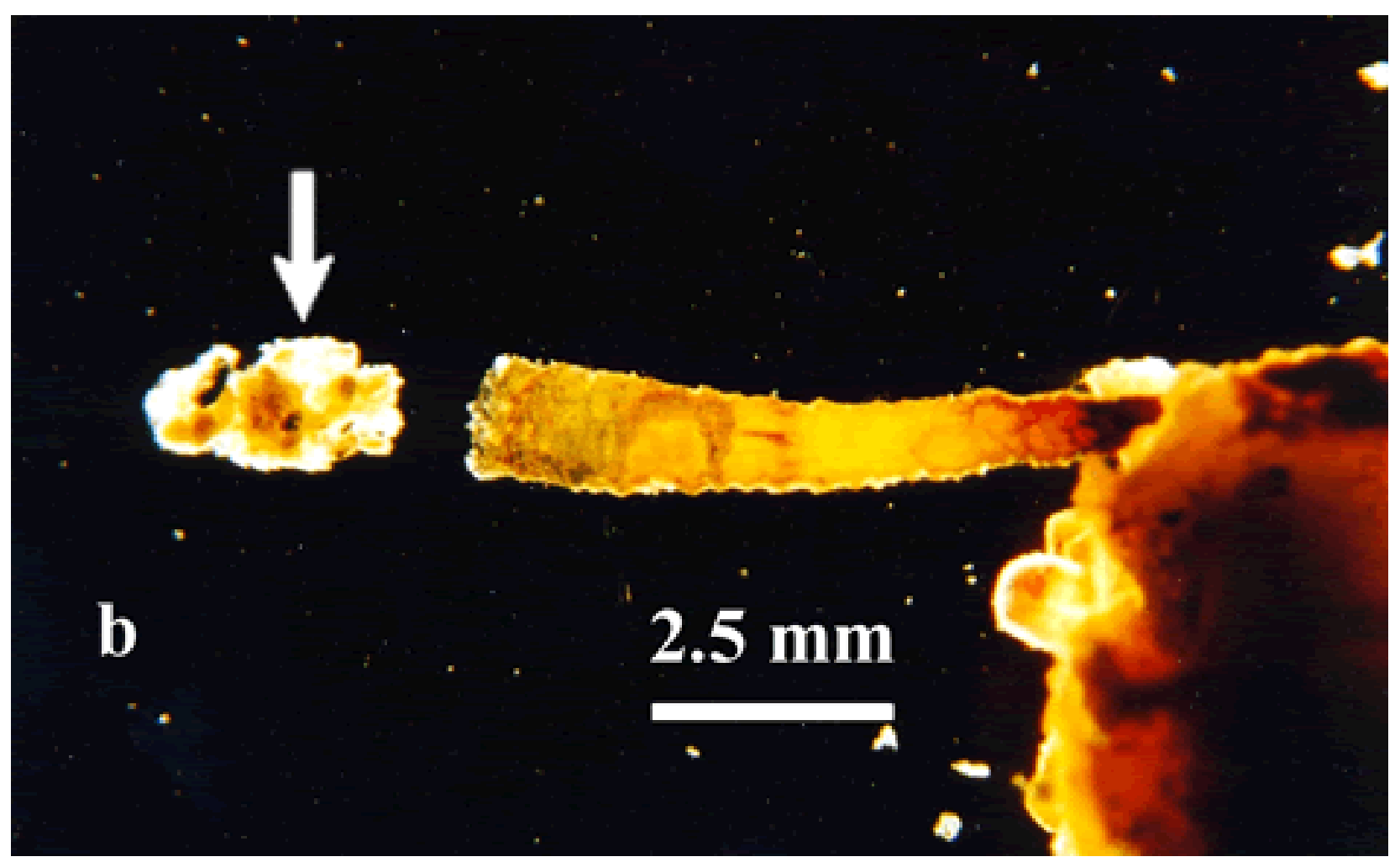

Plate I. Observed aspects of individual stephanoschyphistomae: (b) particles pushed out of the periderm tube by the polyp (arrow); 


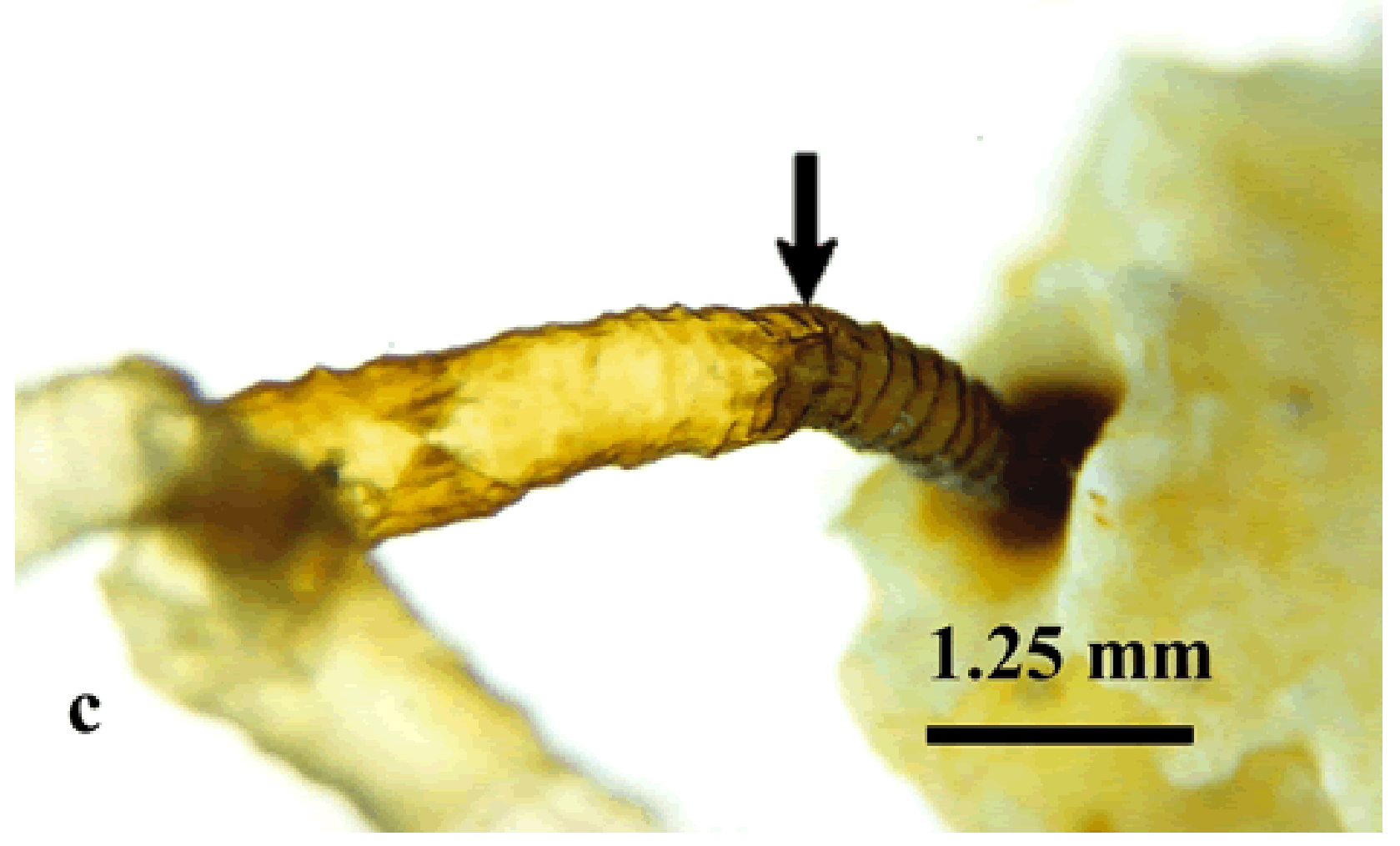

Plate I. Observed aspects of individual stephanoschyphistomae: (c) contracted living tissues within the periderm tube, but not contracting further upon gentle squeeze with delicate forceps;

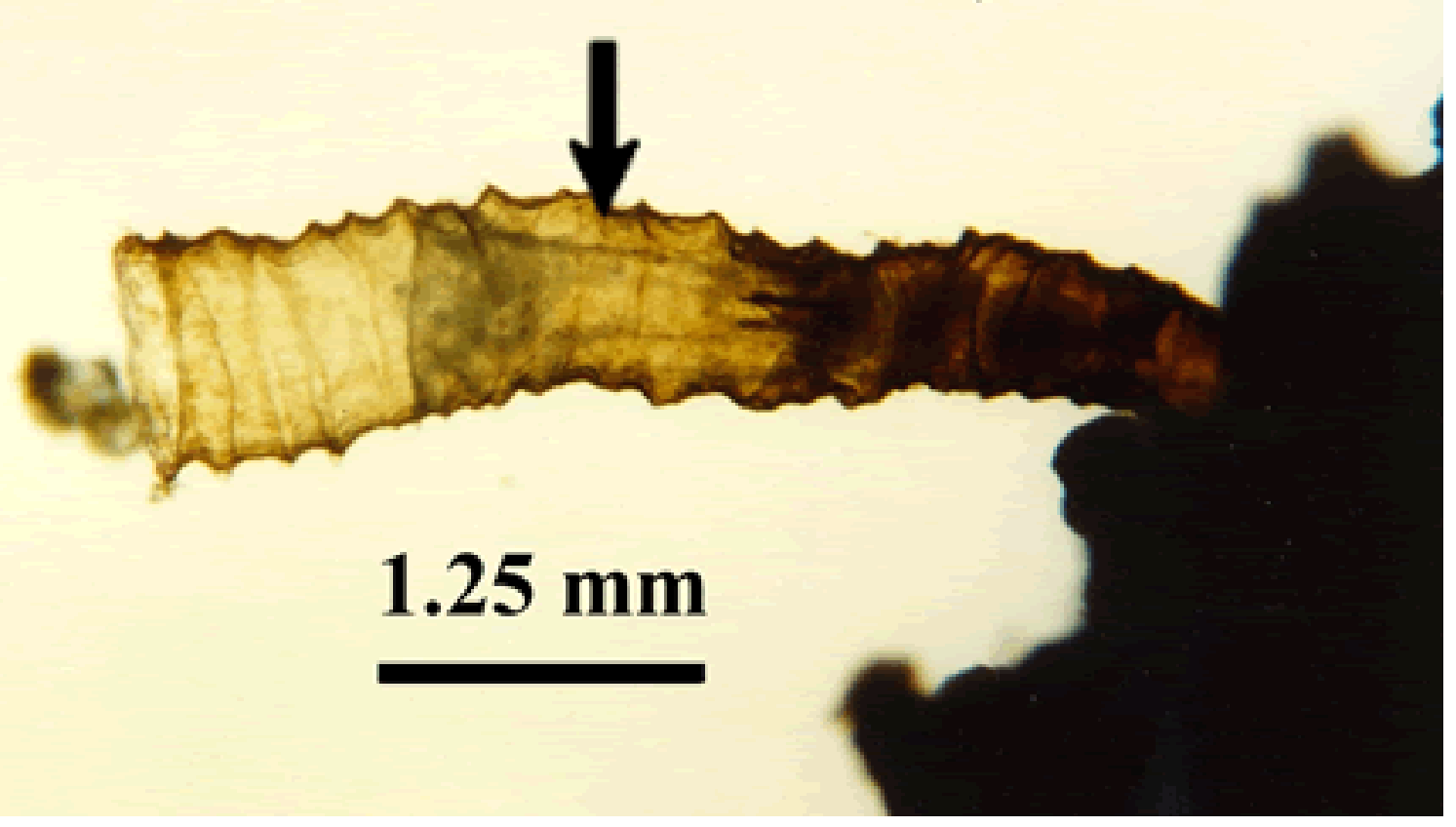

Plate I. Observed aspects of individual stephanoschyphistomae: (d) contracted living tissues within the periderm tube, but still contracting further upon gentle squeeze with delicate forceps;

http://www.biotaneotropica.org.br 


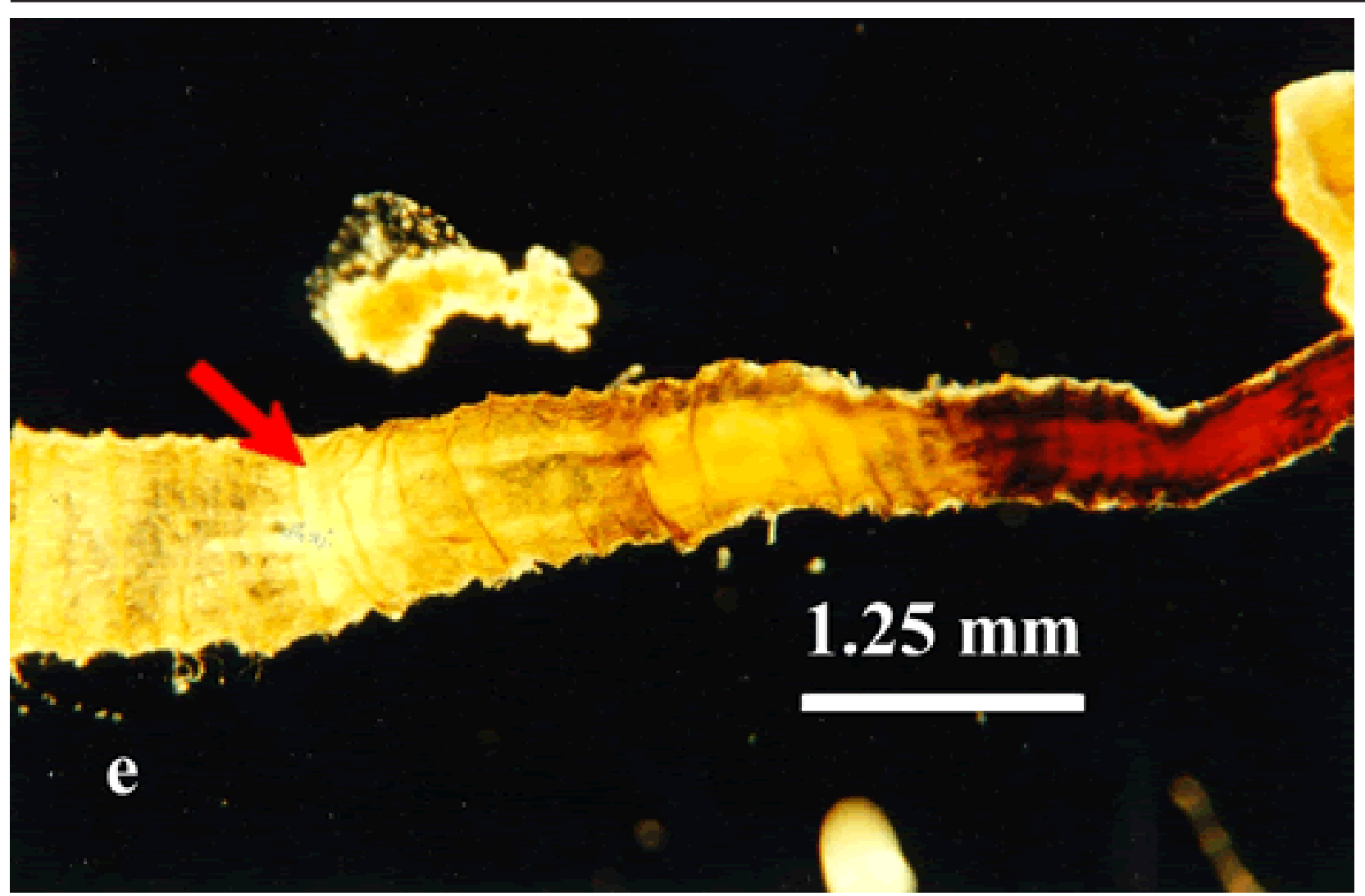

Plate I. Observed aspects of individual stephanoschyphistomae: (e) contracted living tissues within the periderm tube, but oral disk with recognizable tentacles;

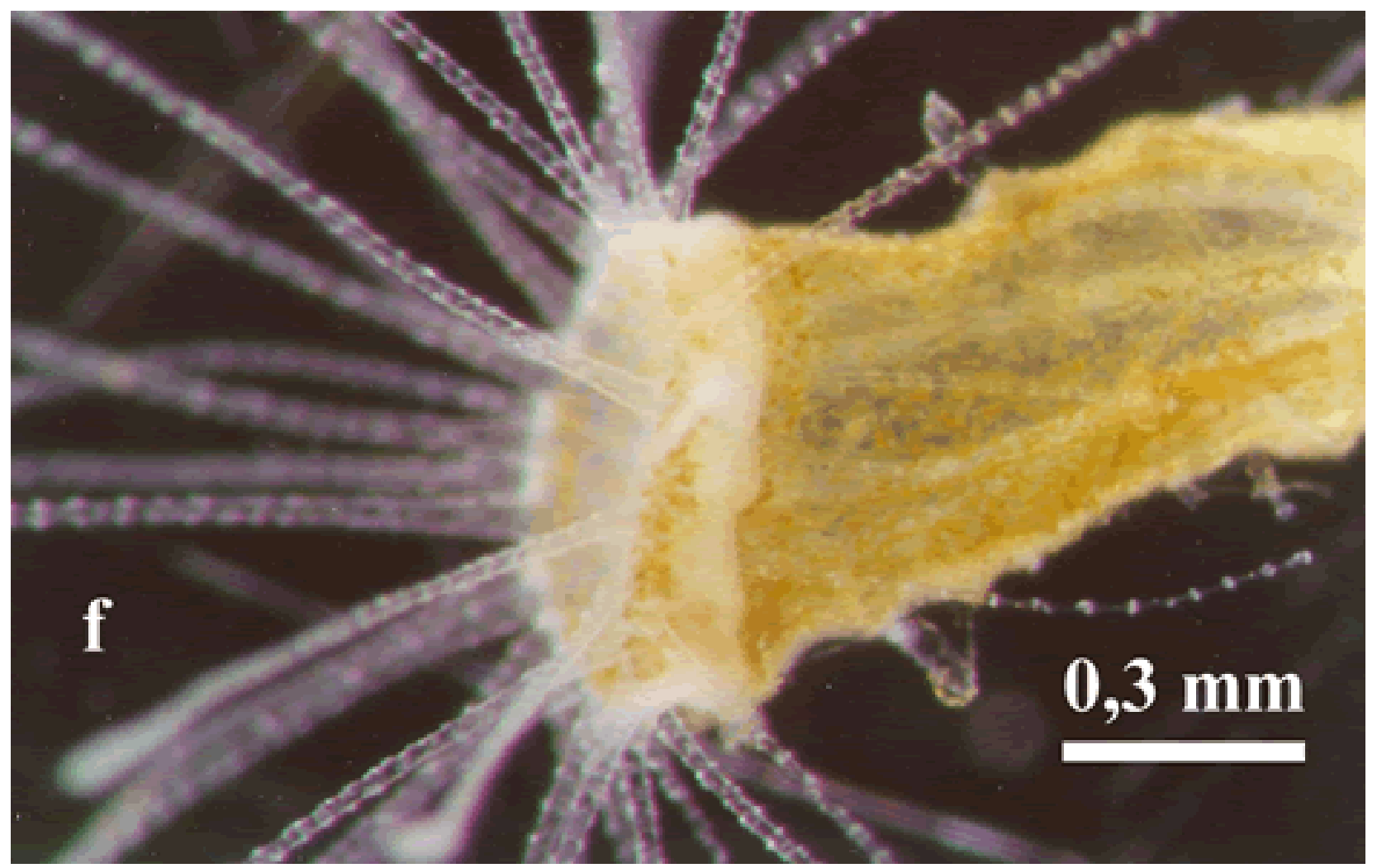

Plate I. Observed aspects of individual stephanoschyphistomae: $(f)$ expanded polyp and oral disc with $\mathbf{n}$ tentacles; $(g)$ polyp with simple column, i.e. without mesenteries or oral disc with tentacles (arrow points to particles); 


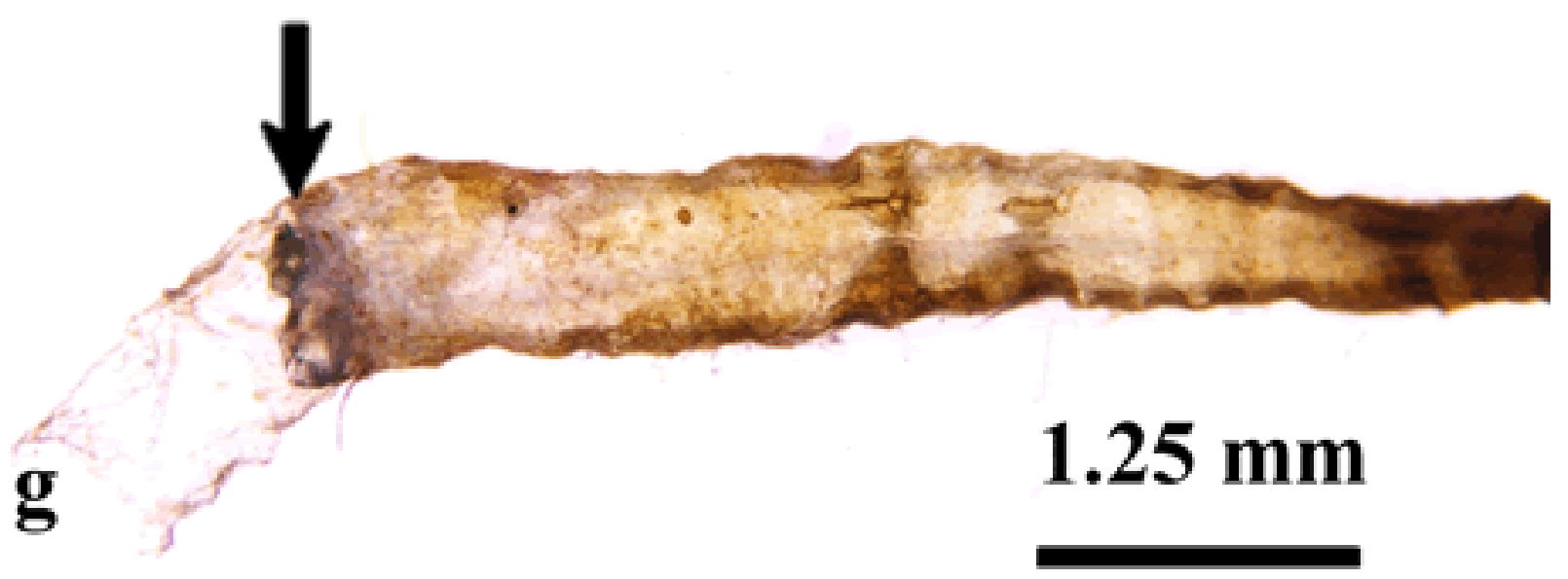

Plate I. Observed aspects of individual stephanoschyphistomae: $(g)$ polyp with simple column, i.e. without mesenteries or oral disc with tentacles (arrow points to particles);

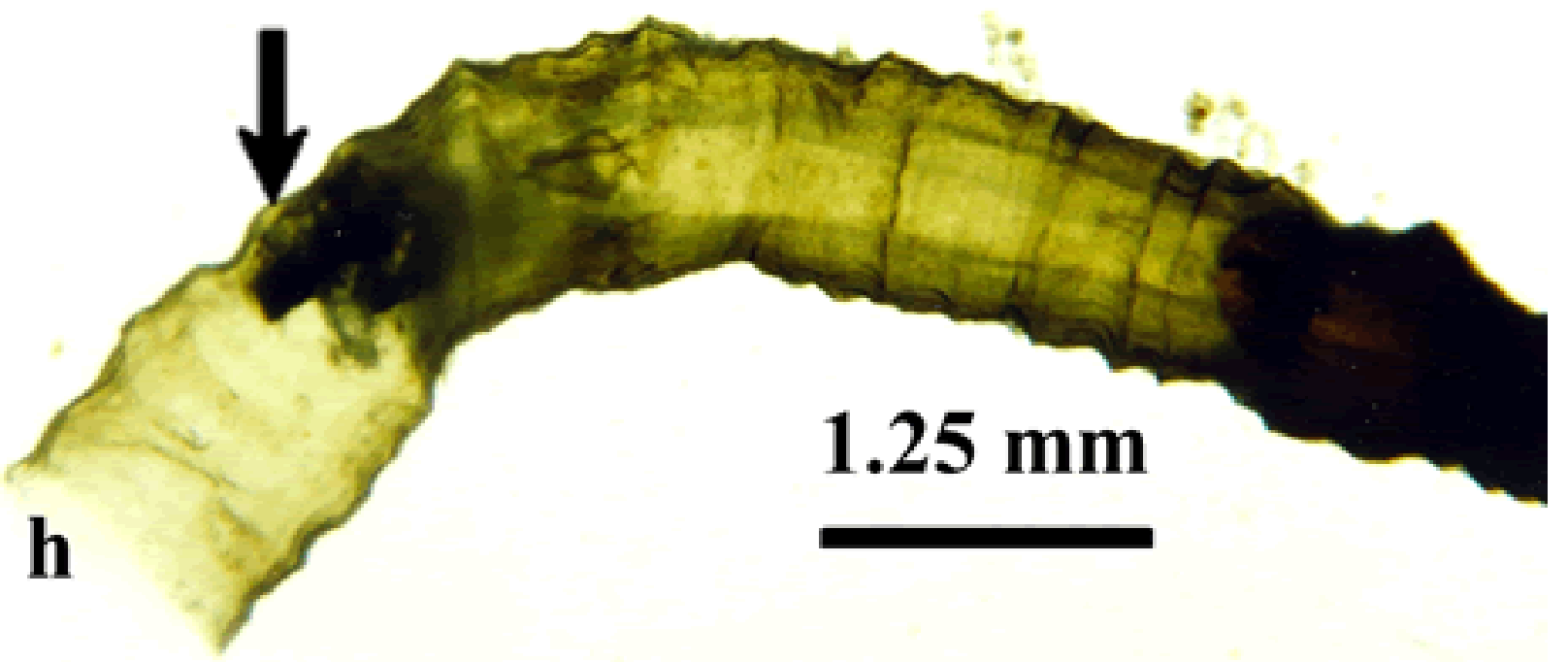

Plate I. Observed aspects of individual stephanoschyphistomae: (h) polyp column with mesenteries, but without oral disc with tentacles (arrow points to particles);

http://www.biotaneotropica.org.br 


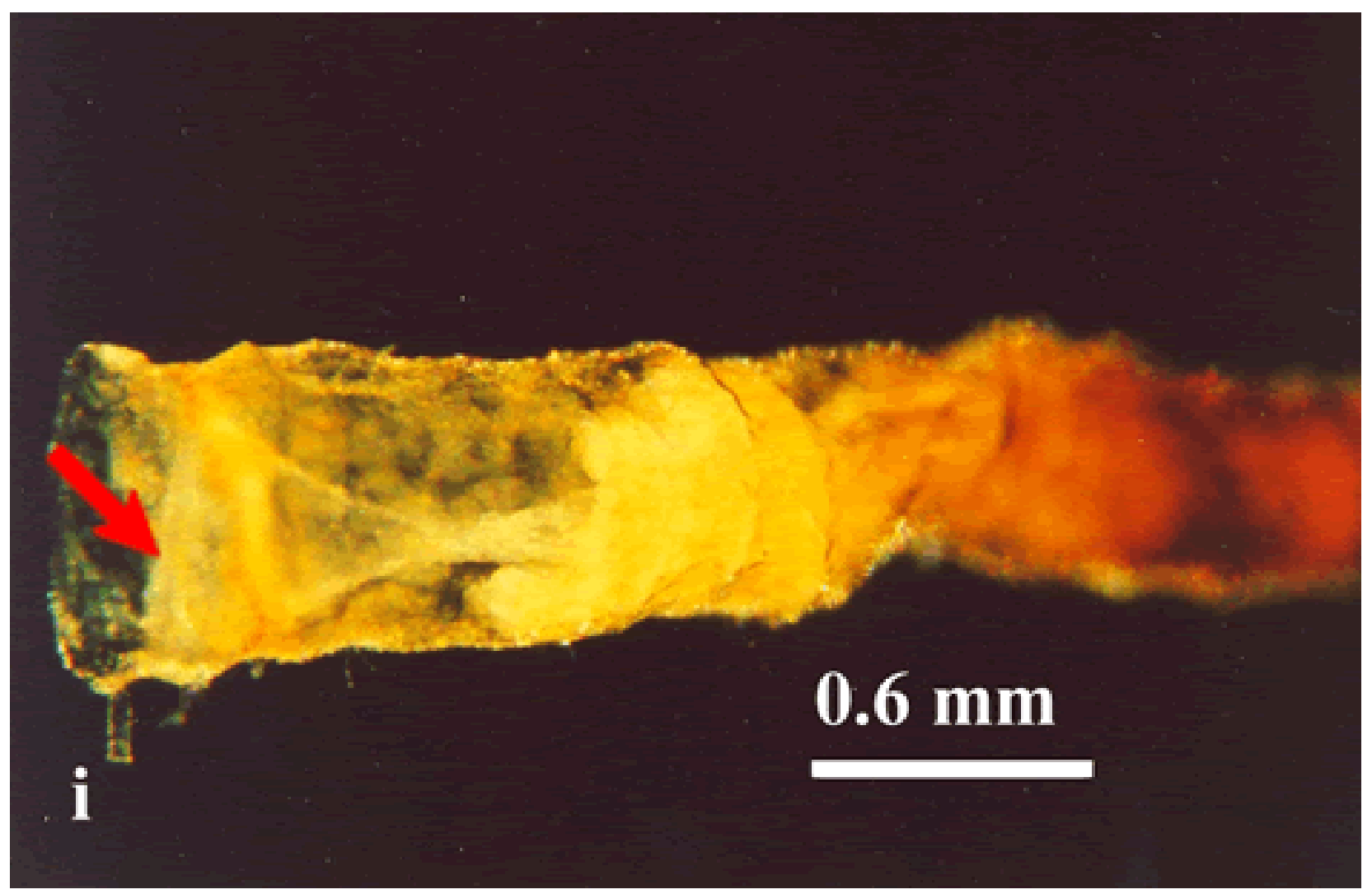

Plate I. Observed aspects of individual stephanoschyphistomae: (i) strobilation under closed periderm operculum (arrow) (note conical head);

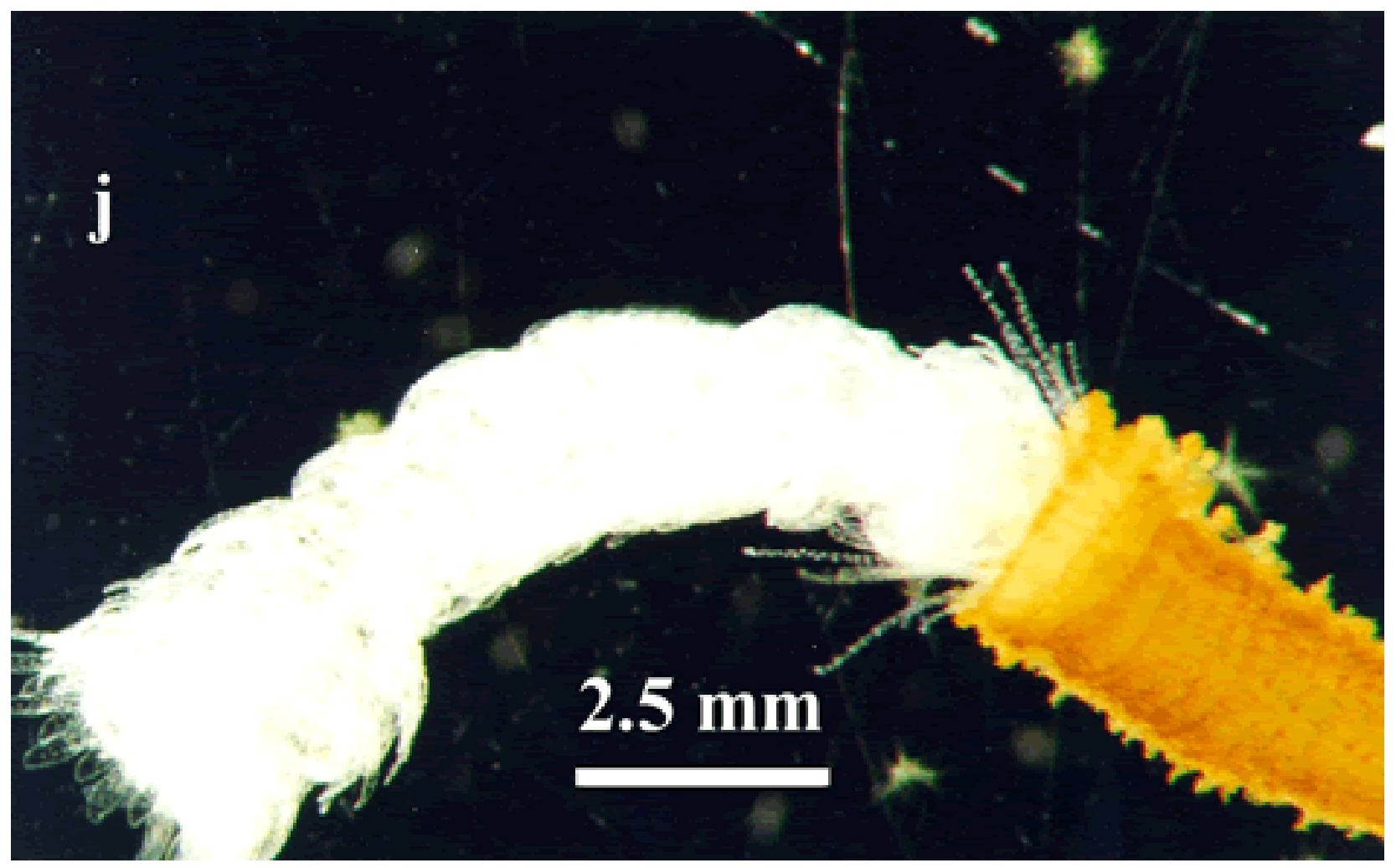

Plate I. Observed aspects of individual stephanoschyphistomae: (j) chain of ephyrae; 


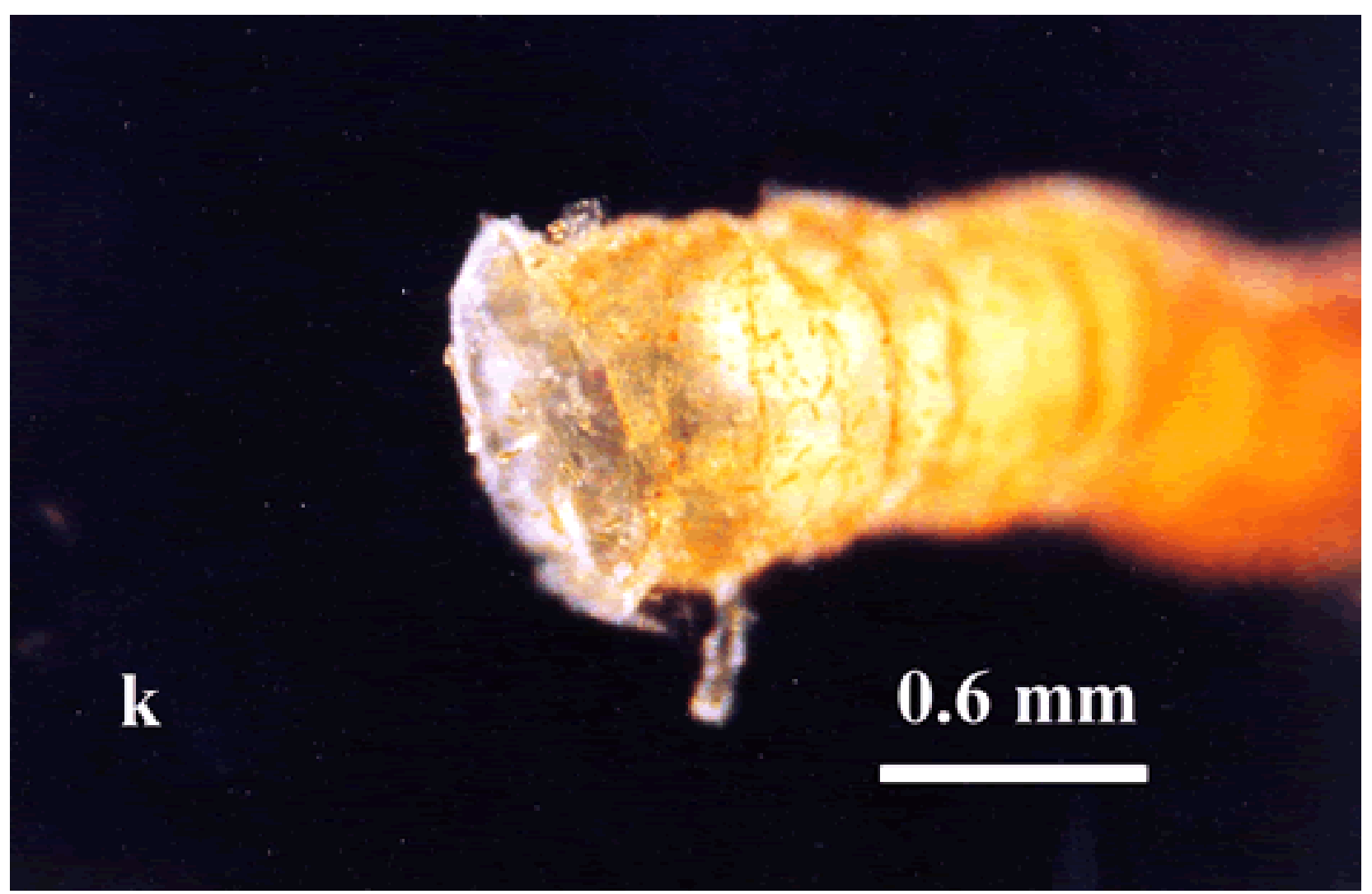

Plate I. Observed aspects of individual stephanoschyphistomae: (k) half opened operculum (arrow);

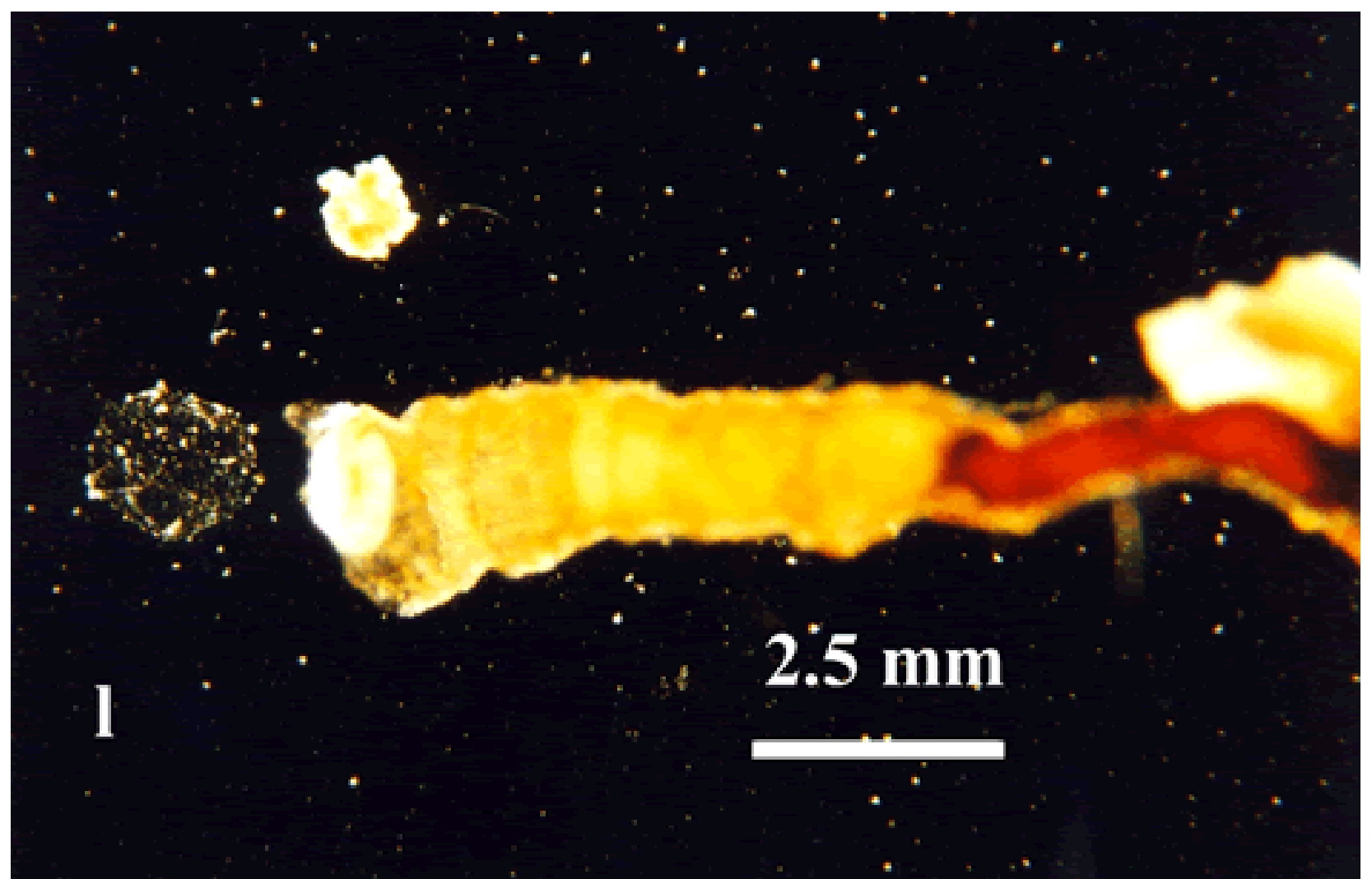

Plate I. Observed aspects of individual stephanoschyphistomae: (l) removed operculum; 


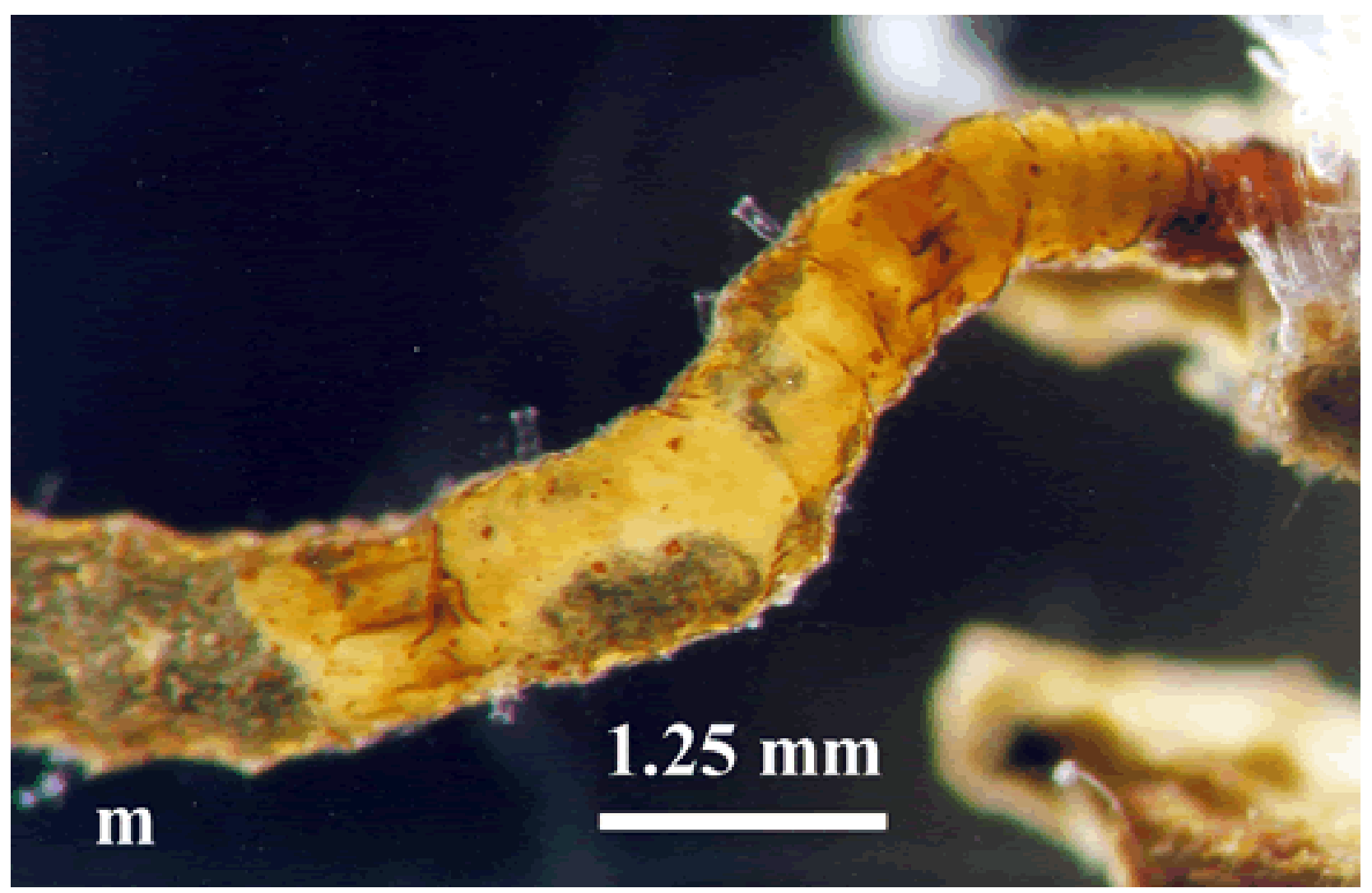

Plate I. Observed aspects of individual stephanoschyphistomae: (m) segmentation;

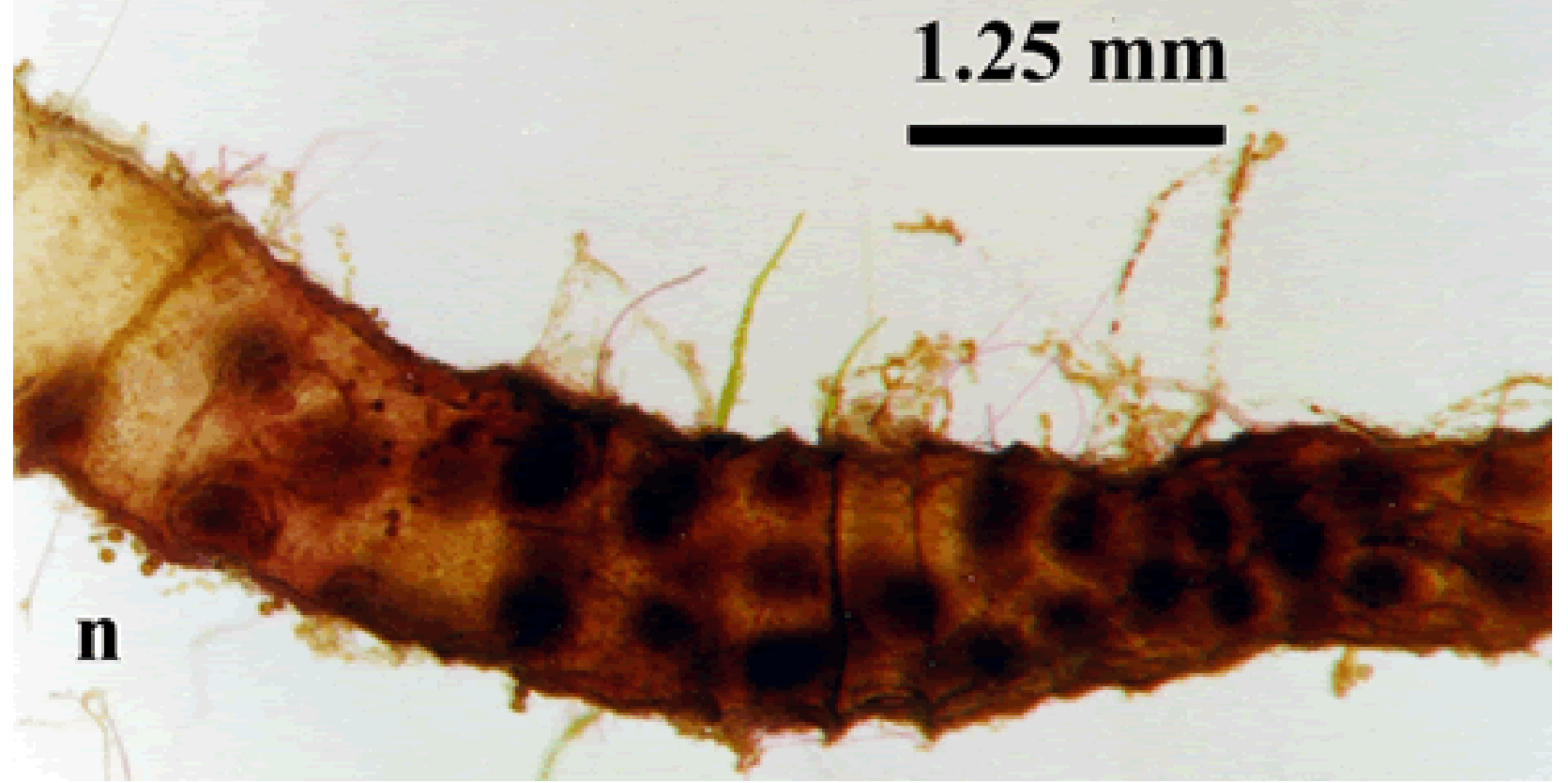

Plate I. Observed aspects of individual stephanoschyphistomae: (n) planuloids (originated by strobilation or fragmentation) within periderm tube;

http://www.biotaneotropica.org.br 


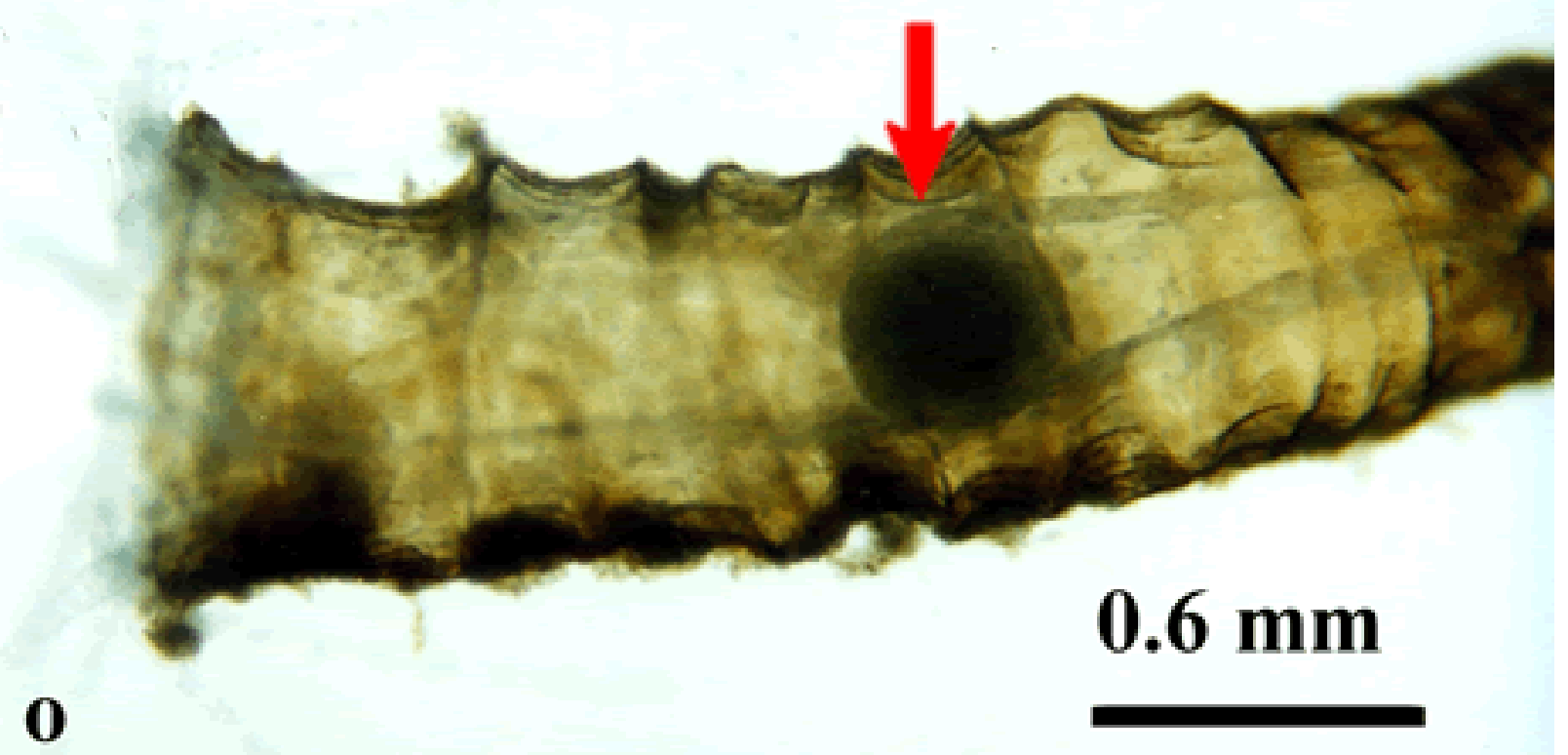

Plate I. Observed aspects of individual stephanoschyphistomae: (o) planuloid inside polyp column (arrow);

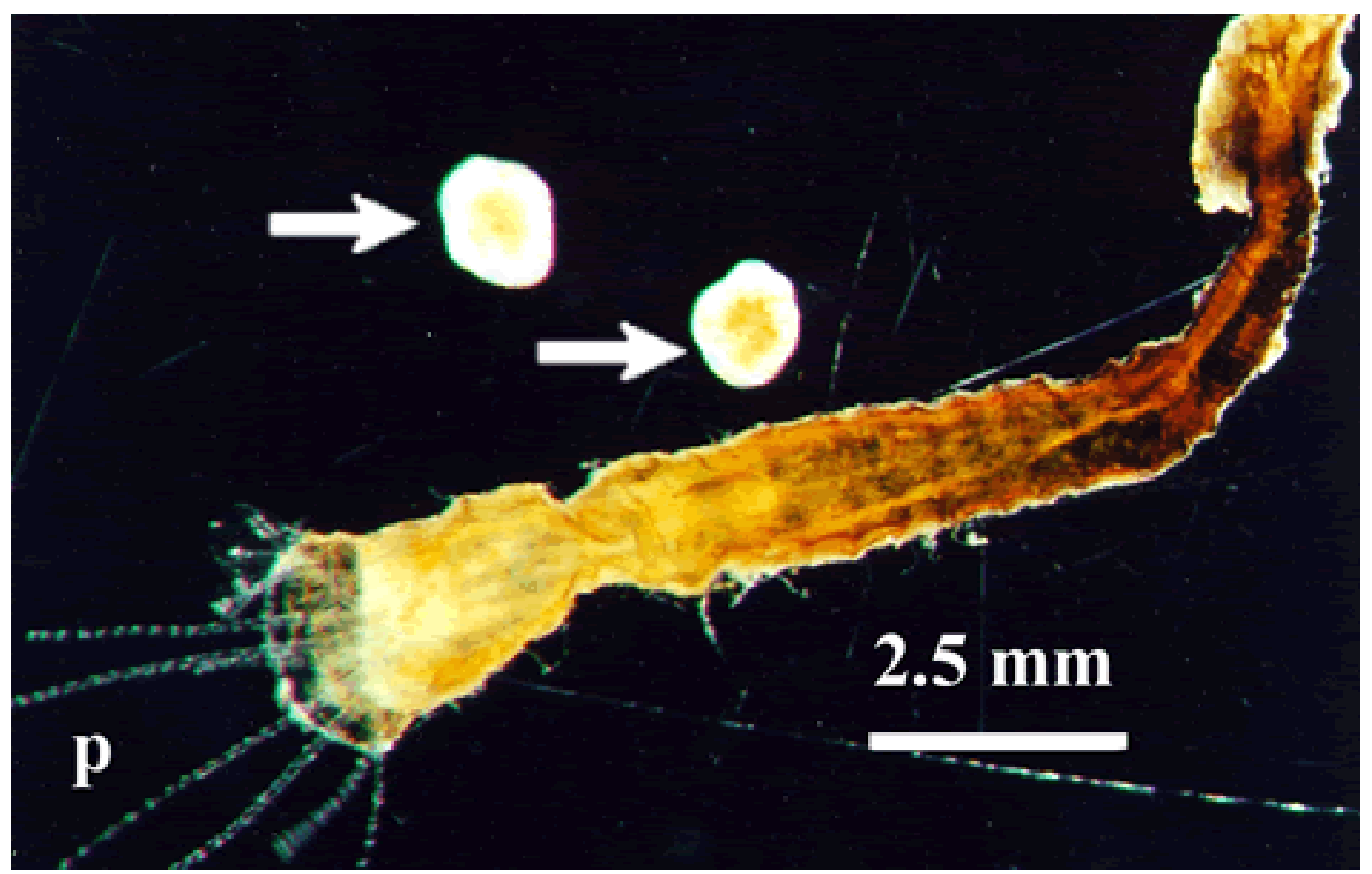

Plate I. Observed aspects of individual stephanoschyphistomae: (p) free planuloids (arrows).

http://www.biotaneotropica.org.br 

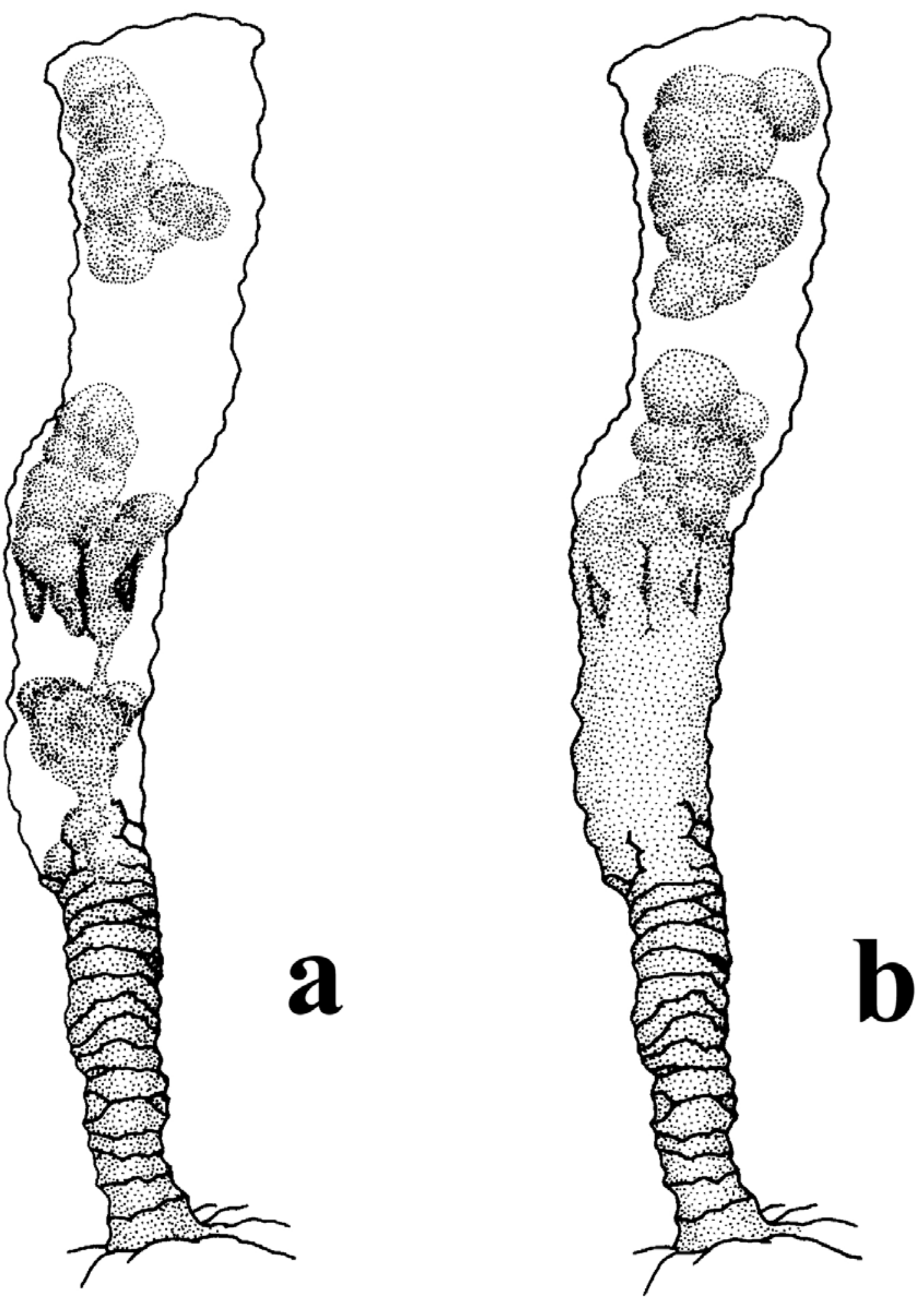

Figure 2. Stephanoscyphistoma of Nausithoe aurea undergoing segmentation (with thin operculum since sampling), regenerating column and retaining planuloids inside the gastrovascular cavity (buried polyp, experiment series). a - Later segmentation stage with planuloid formation and the distal ones almost distinct (24.II.01); $b$-Remaining basal tissues stretch by fusion of less defined planuloids to regenerate the column and distal planuloids separate (25.II.01); 

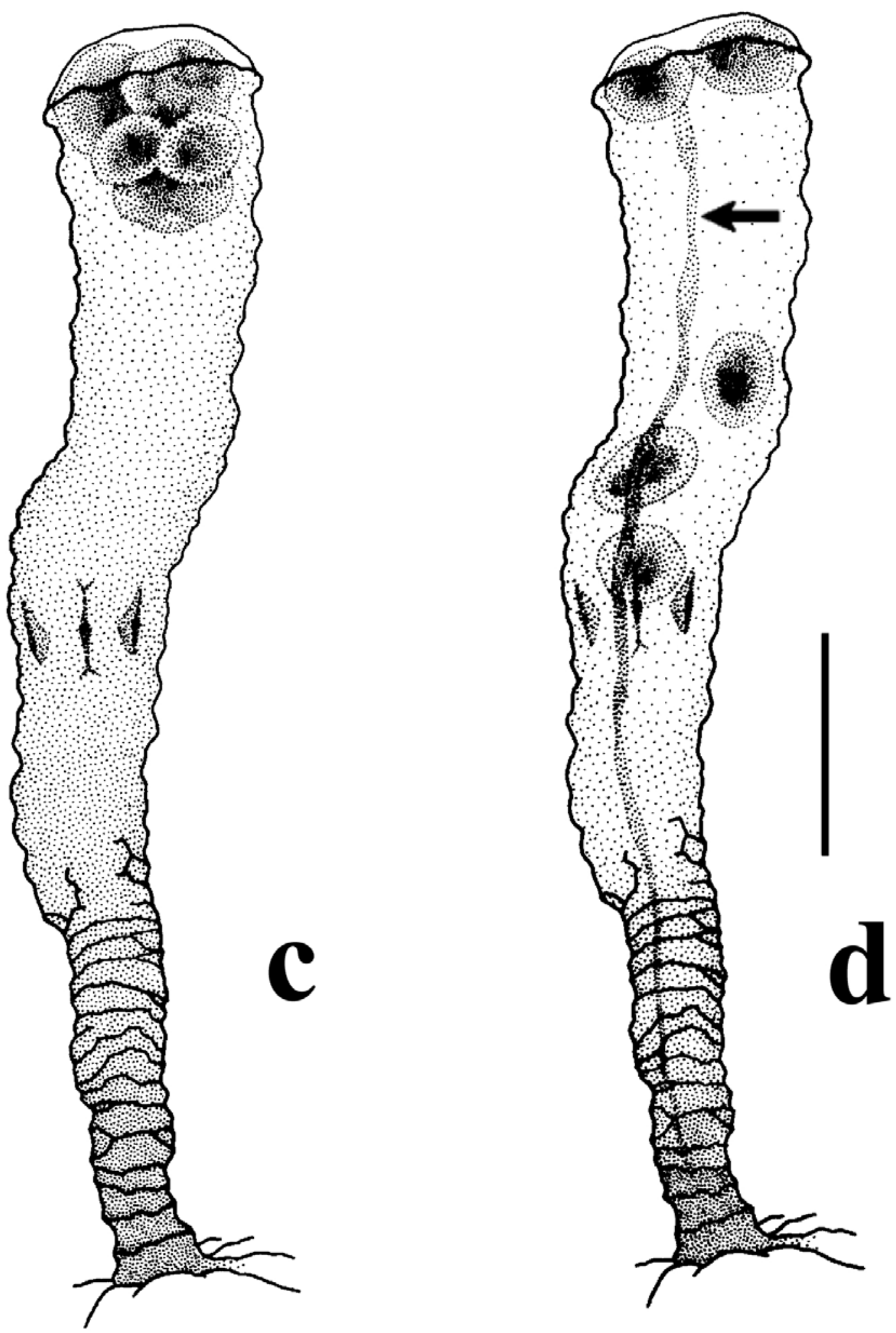

Figure 2. Stephanoscyphistoma of Nausithoe aurea undergoing segmentation (with thin operculum since sampling), regenerating column and retaining planuloids inside the gastrovascular cavity (buried polyp, experiment series). c - Simple regenerated column without the mesenteries, planuloids are distinct and mobile inside the gastrovascular cavity and operculum bulges (27.II.01); $d$ - Regeneration of mesenteries along column (arrow), individual planuloids move inside the gastrovascular cavity and more become distinct under the bulged operculum (03.III.01). Scale: $0.6 \mathrm{~mm}$.

http://www.biotaneotropica.org.br 


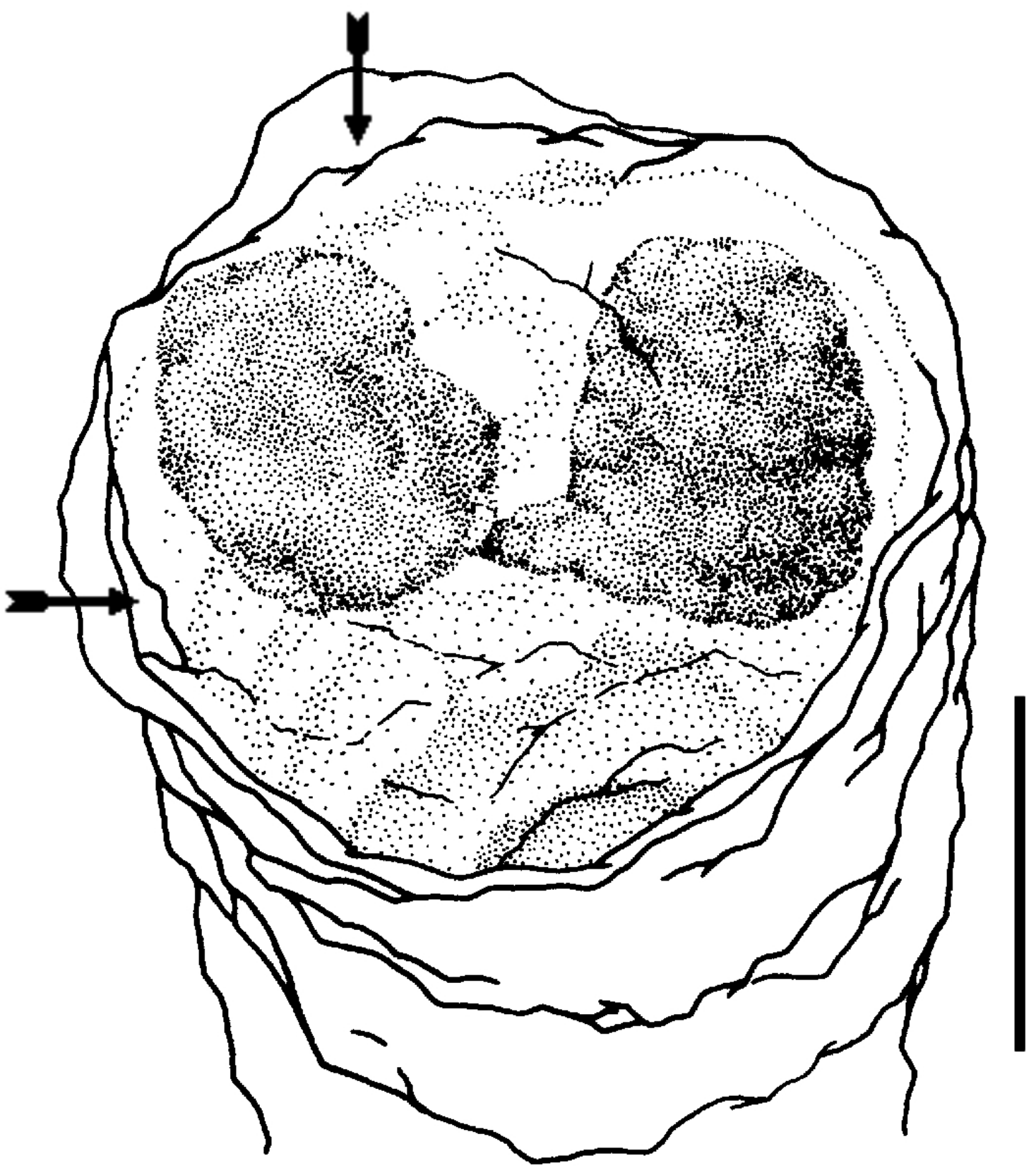

Figure 3. Stephanoscyphistoma periderm tube of Nausithoe aurea, distal end with operculum partially opened (arrows) (6 planuloids had already escaped through the aperture), and with remaining planuloids still becoming distinct (buried polyp, experiment series) (10.III.01). Scale: $0.3 \mathrm{~mm}$. 

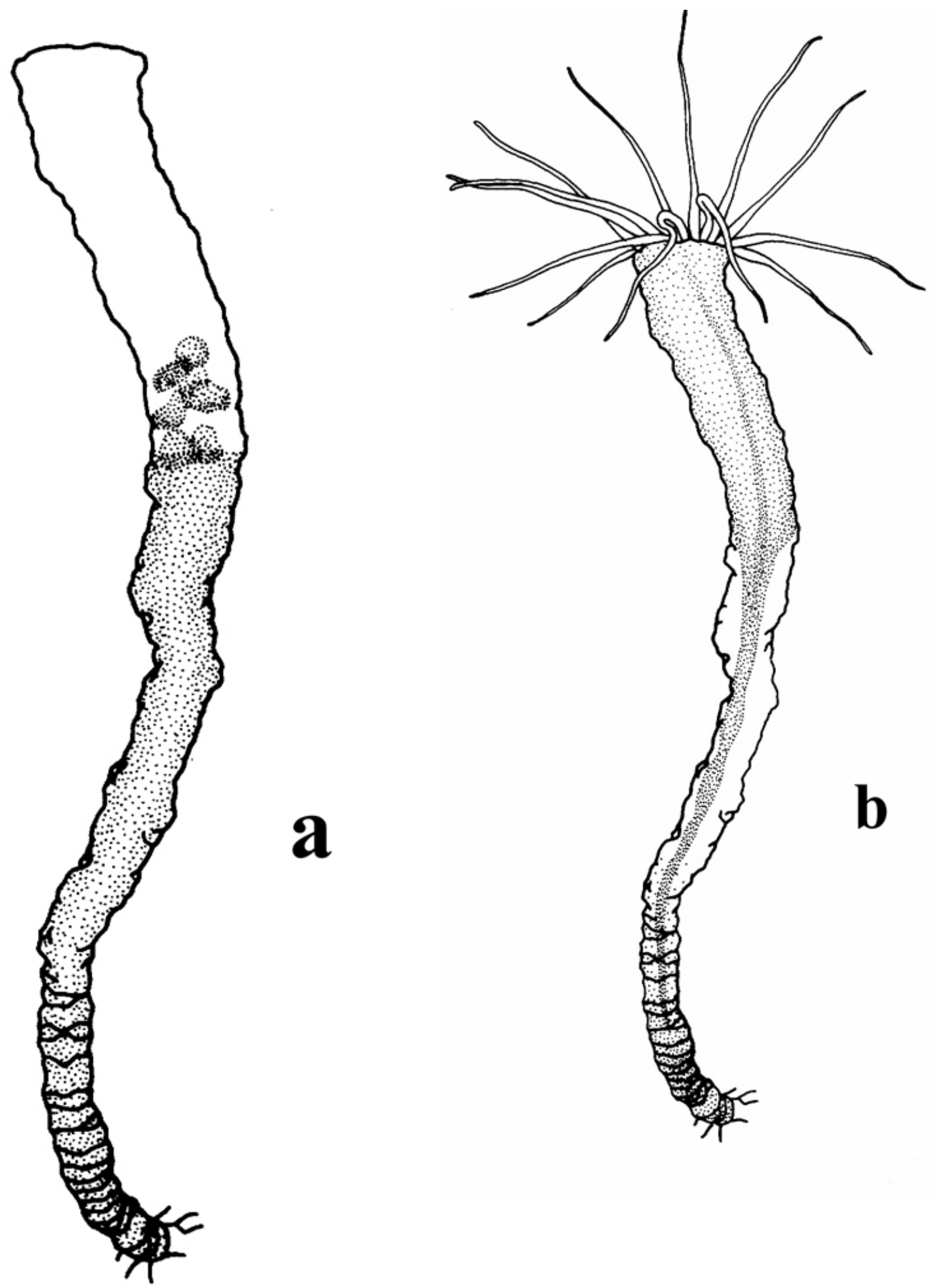

Figure 4. Stephanoscyphistoma of Nausithoe aurea undergoing initial strobilation or segmentation after expulsion of particles, accidental removal of operculum, total regeneration, transverse fission, and alternative segmentation inside the periderm tube closed with an operculum (exposed polyp, control series). a - Stretching of simple polyp column to push particles out of the periderm tube (23.II.01); $b-$ Early regeneration of oral disc after accidental removal of operculum - note the slender column representing stretched condition of the polyp (28.II.01).

http://www.biotaneotropica.org.br 


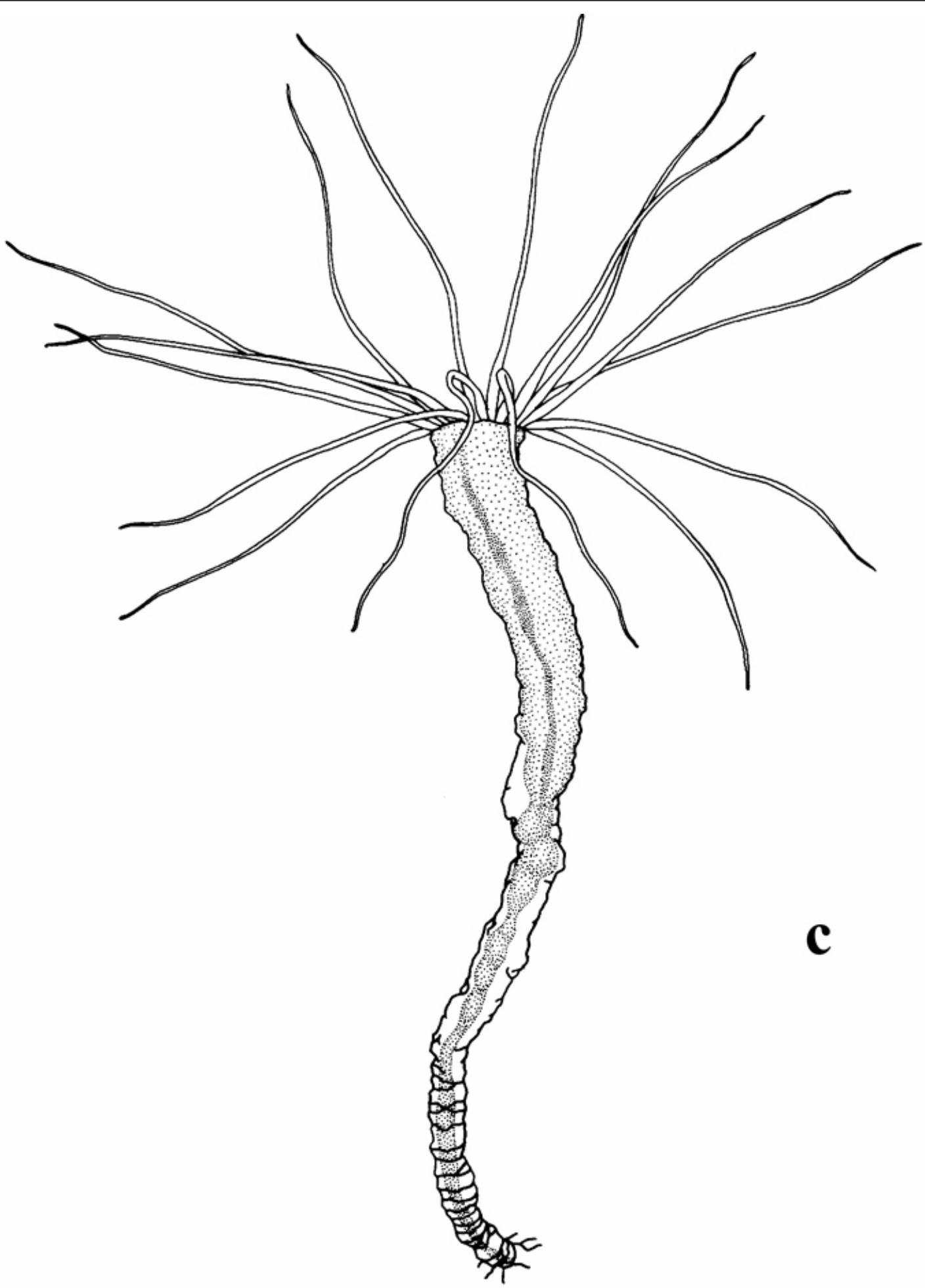

Figure 4. Stephanoscyphistoma of Nausithoe aurea undergoing initial strobilation or segmentation after expulsion of particles, accidental removal of operculum, total regeneration, transverse fission, and alternative segmentation inside the periderm tube closed with an operculum (exposed polyp, control series). c - Multiple constrictions along the basal tissues and a strong knot halfway the polyp column $(03 / 03 / 01)$;

http://www.biotaneotropica.org.br 

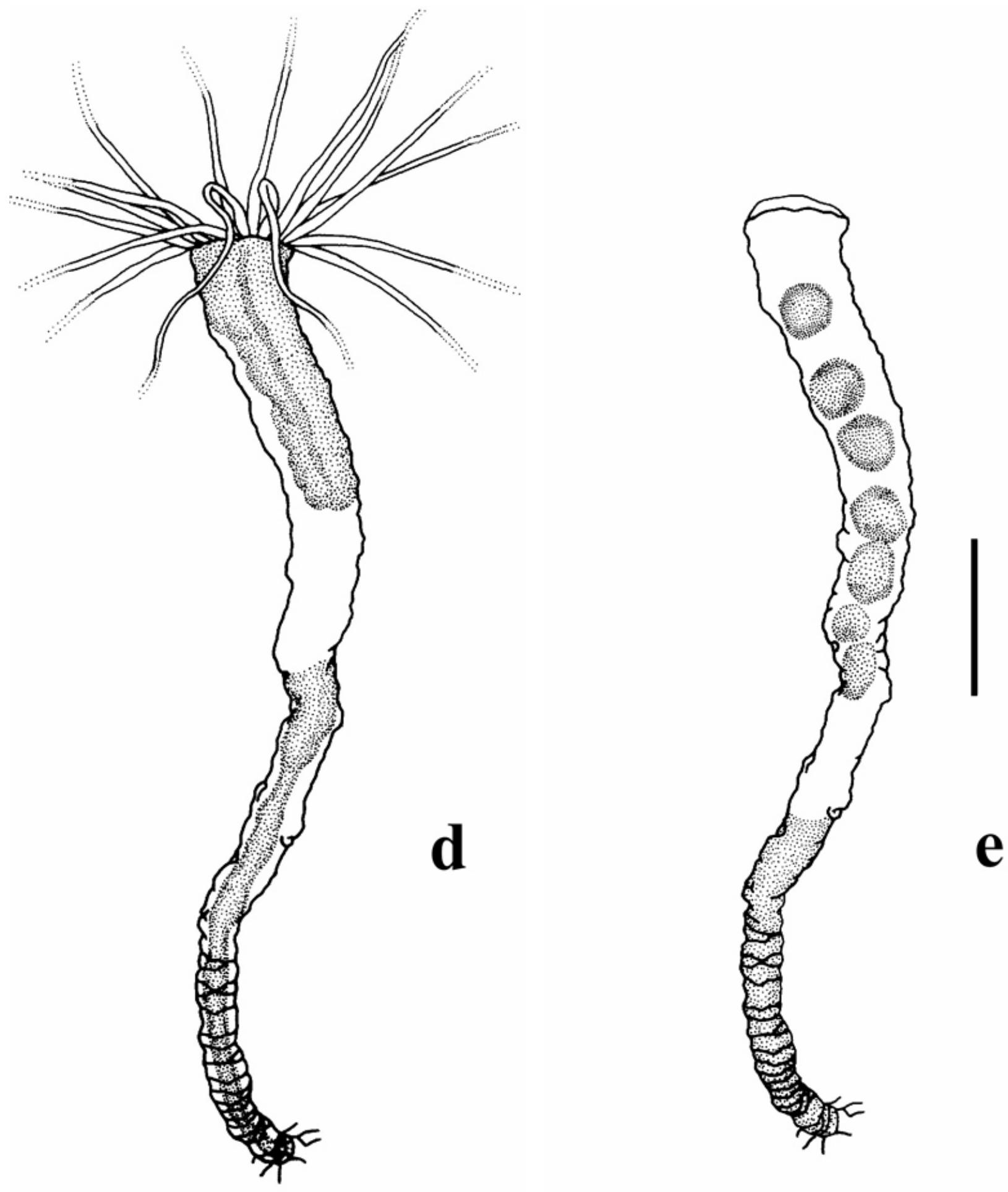

Figure 4. Stephanoscyphistoma of Nausithoe aurea undergoing initial strobilation or segmentation after expulsion of particles, accidental removal of operculum, total regeneration, transverse fission, and alternative segmentation inside the periderm tube closed with an operculum (exposed polyp, control series). $d$-Active feeding 'head' in distal part and simplified basal tissues of divided column (12.III.01). $e$-Operculum and many planuloids inside the periderm tube resulted from segmentation of distal part of severed column (26.III.01). Scale: $0.6 \mathrm{~mm}$.

http://www.biotaneotropica.org.br 

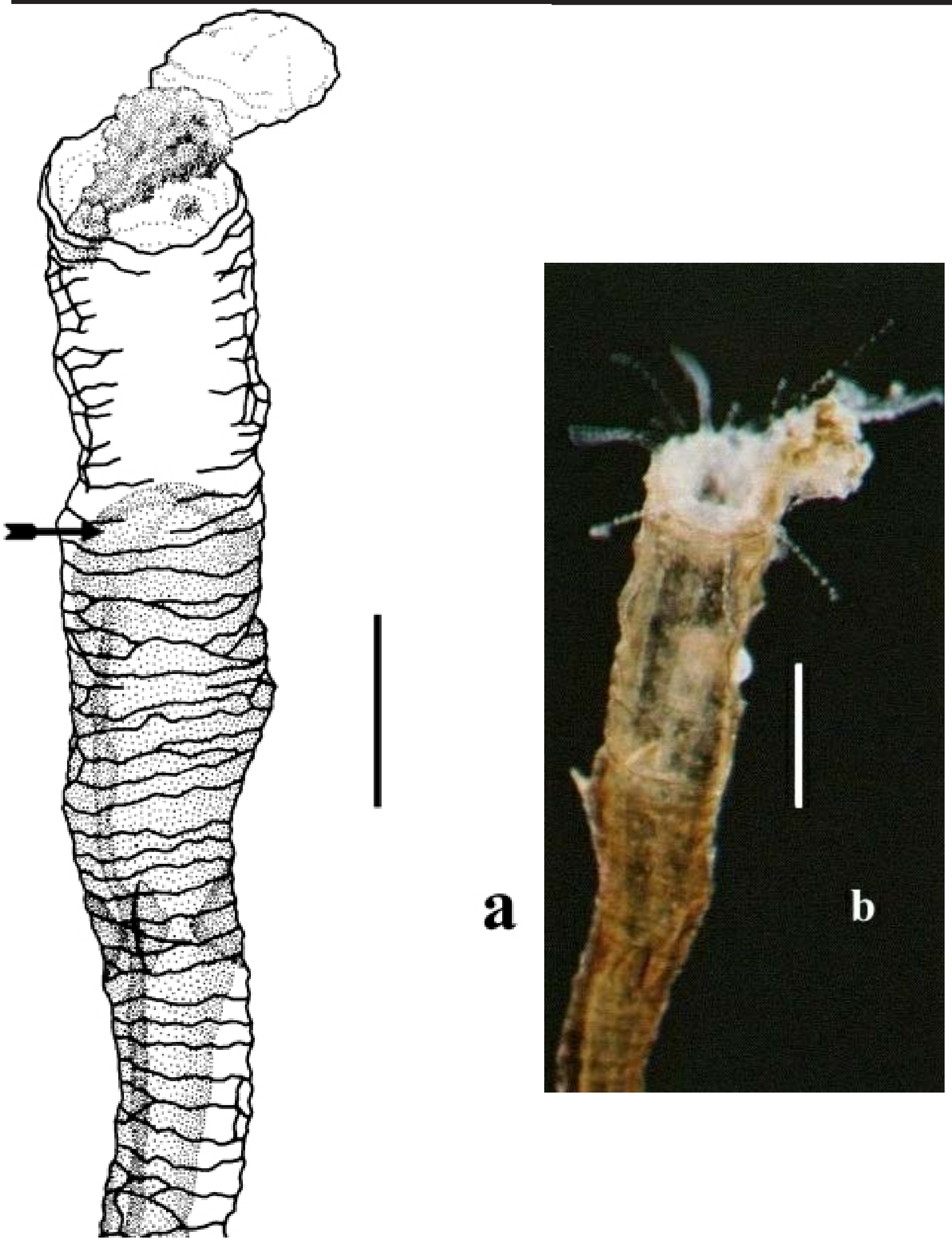

Figure 5. Stephanoscyphistoma of Nausithoe aurea opening the operculum after segmentation and ingesting residual tissues following regeneration of the oral disc (buried polyp, experiment series). a-Contraction of the column without oral disc with tentacles (arrow), upon stimulation with a forceps, to show residual tissues on the margin of the periderm tube aperture (07.VIII.01). $b-O r a l$ disc with 13 short tentacles and polyp ingests the residual tissues (08.VIII.01). Scales: $0.3 \mathrm{~mm}$

http://www.biotaneotropica.org.br 


\begin{tabular}{|c|c|c|c|c|c|}
\hline & \multicolumn{3}{|c|}{ EXPECTED } & \multicolumn{2}{|c|}{ NO VEL } \\
\hline & Part. & Oper. & $\begin{array}{l}\text { Part. + } \\
\text { Oper. }\end{array}$ & Part. & Oper. \\
\hline Jul 00-12p & & 4 (Ex) & $1(\mathrm{Ex})$. & & $5 \mathrm{~S}(2 \mathrm{Ex} .3 \mathrm{Br})$. \\
\hline Aug-Sep 00 - & & $\frac{3\left(2 E_{x}-1\right.}{\mathrm{Br})}$ & & & \\
\hline Sep-Oct $00-12 p$ & $\begin{array}{c}2(1 \mathrm{Ex} . \\
1 \mathrm{Br} .)\end{array}$ & $\begin{array}{c}1(\mathrm{Br}) \\
5(2 \mathrm{Ex} .3 \mathrm{Br})\end{array}$ & $1(\mathrm{Ex})$. & & $1 \mathrm{~S}(\mathrm{~B} x)$ \\
\hline $\begin{array}{c}\text { Oct-Now } 00 \text { - } \\
\text { 12p }\end{array}$ & $\begin{array}{c}2(1 \mathrm{Ex} . \\
1 \mathrm{Br})\end{array}$ & $2(1 \mathrm{Ex}, 1 \mathrm{Br})$ & & & $2 S(\mathrm{Ex})$ \\
\hline $\begin{array}{c}\text { Nov-Dec 00 - } \\
\text { 12p }\end{array}$ & $5(\mathrm{Br})$ & $4(1 \mathrm{Ex}, 3 \mathrm{Br})$ & & & $2 \mathrm{~S}(1 \mathrm{Ex} .1 \mathrm{Br})$ \\
\hline $\begin{array}{c}\text { Dec 00-Jan 01 - } \\
\text { 12p } \\
\end{array}$ & $\begin{array}{c}\text { 4(1Ex. } \\
3 \mathrm{Br} .) \\
\end{array}$ & $3(1 \mathrm{Ex} 2 \mathrm{2Br})$ & & $1 \mathrm{~S}(\mathrm{Ex})$. & $\begin{array}{l}1 \mathrm{D}(\mathrm{Ex}) \\
\text { 2S (Br) } \\
\end{array}$ \\
\hline $\begin{array}{c}\text { Jan-Feb 01 - } \\
\text { 12p }\end{array}$ & $3(\mathrm{Br})$ & $\begin{array}{l}2(1 \mathrm{Ex} .1 \mathrm{Br}) \\
5(3 \mathrm{Ex} .2 \mathrm{Br})\end{array}$ & & & $2 \mathrm{~S}$ (1Ex. 1Br.) \\
\hline $\begin{array}{c}\text { Feb-Mar } 01 \text { - } \\
\text { 12p }\end{array}$ & 1 (Br.) & $\begin{array}{c}2(\mathrm{Br}) \\
2(1 \mathrm{Ex}, \mathrm{Br})\end{array}$ & $3(2 \mathrm{Ex} .1 \mathrm{Br})$. & & $2 \mathrm{2S}(1 \mathrm{Ex} .1 \mathrm{Br})$. \\
\hline $\begin{array}{c}\text { Mar-Apr } 01 \text { - } \\
9 \mathrm{p}\end{array}$ & $1(\mathrm{Br})$. & $2(\mathrm{Ex})$. & & & $\begin{array}{c}1 \mathrm{~S}(\mathrm{Ex}) \\
2 \mathrm{~S}(1 \mathrm{Ex} / \mathrm{Br})\end{array}$ \\
\hline May 01 - 12p & & $\begin{array}{l}5(\mathrm{Br}) \\
2(\mathrm{Ex})\end{array}$ & 1 (Ex.) & $1 \mathrm{D}(\mathrm{Br})$. & \\
\hline $\begin{array}{c}\text { May-Jun01 - } \\
\text { 12p }\end{array}$ & $2(\mathrm{Br})$ & $\begin{array}{c}2(\mathrm{Br}) \\
5(3 \mathrm{Ex} .2 \mathrm{Br})\end{array}$ & & & \\
\hline Aug 01 - 12p & $\begin{array}{c}3(2 \mathrm{Ex} . \\
1 \mathrm{Br} .)\end{array}$ & $2(\mathrm{Br})$. & $1(\mathrm{Br})$. & & $1 \mathrm{~S}(\mathrm{Ex})$. \\
\hline
\end{tabular}

Table 2: Observations within the control series of the expected and novel aspects (dormancy or segmentation) for the biology Nausithoe aurea related to the possibilities that the periderm tubes were closed by particles (Part.), or by an operculum (Oper.), or by particles and operculum (Part. + Oper.). Abbreviations: Br. = buried scyphistoma; $D=$ dormancy; Ex. = exposed scyphistoma; $\mathrm{n} p=\mathrm{number}$ of polyps under observation; $S=$ segmentation. $\underline{\text { Underlined }}=$ observed under laboratory conditions. 


\begin{tabular}{|c|c|c|c|c|c|}
\hline & \multicolumn{3}{|c|}{$\begin{array}{c}\text { EXPECTE } \\
\text { D }\end{array}$} & \multicolumn{2}{|c|}{ NO VEL } \\
\hline & Part. & Oper. & $\begin{array}{l}\text { Part + } \\
\text { Oper. }\end{array}$ & Part. & Oper. \\
\hline $\begin{array}{l}\text { Aug-Sep } 00 \text { - } \\
\text { 12p }\end{array}$ & $1(\mathrm{Ex})$ & $3(\mathrm{Ex})$ & $1(\mathrm{Ex})$. & & $1 S\left(\mathrm{Ex}_{x}\right)$ \\
\hline $\begin{array}{c}\text { Sep-Oct } 00 \text { - } \\
\text { 12p }\end{array}$ & $\begin{array}{c}4(1 \mathrm{Ex} . \\
3 \mathrm{Br} .)\end{array}$ & $\begin{array}{l}2(\mathrm{Br}) \\
2(\mathrm{Br}) \\
\end{array}$ & & & $\begin{array}{l}\frac{3 \mathrm{~S}(2 \mathrm{Ex}}{1 \mathrm{Br} .)} \\
\end{array}$ \\
\hline $\begin{array}{l}\text { Oct-Now } 00 \text { - } \\
\text { 12p }\end{array}$ & $1(\mathrm{Ex})$. & & & & $1 \overline{\mathrm{D}(\mathrm{Br} .)}$ \\
\hline $\begin{array}{l}\text { Nov-Dec 00 - } \\
\text { 12p }\end{array}$ & $\begin{array}{c}5(1 \mathrm{Ex} . \\
4 \mathrm{Br} .)\end{array}$ & $\frac{4(2 \mathrm{Ex}}{2 \mathrm{Br})}$ & & $1 \mathrm{D}(\mathrm{Br})$. & $1 \mathrm{~S}(\mathrm{Ex})$ \\
\hline $\begin{array}{c}\text { Dec 00-Jan } 01 \\
\text { - 12p }\end{array}$ & $5(\mathrm{Br})$. & $\begin{array}{c}1(\mathrm{Ex}) \\
\frac{3(2 \mathrm{Ex} .1}{\mathrm{Br})}\end{array}$ & & & \\
\hline $\begin{array}{c}\text { Jan-Feb } 01 \text { - } \\
\text { 12p }\end{array}$ & $3(\mathrm{Br})$. & $\frac{6(4 \mathrm{Ex} .}{2 \mathrm{~B} x)}$ & & & $1 \mathrm{D}(\mathrm{Br})$. \\
\hline $\begin{array}{c}\text { Feb-Mar } 01 \text { - } \\
\text { 12p }\end{array}$ & $\begin{array}{c}3(2 \mathrm{Ex}, \\
1 \mathrm{Br} .)\end{array}$ & $\begin{array}{l}1(\mathrm{Br}) \\
2(\mathrm{Br})\end{array}$ & & & $\begin{array}{l}1 \mathrm{~S}(\mathrm{Br}) \\
2 \mathrm{~S}(\mathrm{Ex})\end{array}$ \\
\hline Mar-Apr 01 - Tp & $\begin{array}{c}3(2 \mathrm{Ex} . \\
1 \mathrm{Br})\end{array}$ & & & $2 \mathrm{~S}(\mathrm{Br})$. & $\begin{array}{l}1 \mathrm{~S}(\mathrm{Br}) \\
2 \mathrm{~S}(\mathrm{Br})\end{array}$ \\
\hline May 01 - 12p & $\begin{array}{l}3(1 \mathrm{Ex} . \\
2 \mathrm{Br} .)\end{array}$ & & 1 (Br.) & $\begin{array}{c}1 \mathrm{~S}(\mathrm{Br}) \\
3 \mathrm{D}(1 \mathrm{Ex} . \\
2 \mathrm{Br} .)\end{array}$ & $1 \mathrm{D}(\mathrm{Ex})$ \\
\hline $\begin{array}{c}\text { May-Jun } 01 \text { - } \\
\text { l2p }\end{array}$ & $5(\mathrm{Br})$. & $\begin{array}{l}2(\mathrm{Ex}) \\
1(\mathrm{Ex})\end{array}$ & $1(\mathrm{Br})$ & & \\
\hline Aug 01 - 12p & $5(\mathrm{Ex})$ & $3(\mathrm{Ex})$. & $1(\mathrm{Ex})$ & $1 \mathrm{D}(\mathrm{Br})$ & $\begin{array}{l}1 \mathrm{~S}(\mathrm{Ex}) \\
1 \mathrm{~S}(\mathrm{Ex})\end{array}$ \\
\hline
\end{tabular}

Table 3: Observations within the experimental series of the expected and novel aspects (dormancy or segmentation) for the biology Nausithoe aurea related to the possibilities that the periderm tubes were closed by particles (Part.), or by an operculum (Oper.), or by particles and operculum (Part. + Oper.). Abbreviations: Br. = buried scyphistoma; $D=$ dormancy; Ex. = exposed scyphistoma; $\mathrm{n} p=$ number of polyps under observation; $S=$ segmentation. Underlined $=$ observed under laboratory conditions. 
Examining Table 2, the polyps that showed expected aspects for the biology of $N$. aurea, we noticed that: 2 $(1.41 \%)$ with particles -1 buried in dormancy and 1 exposed in segmentation; $21(14.8 \%)$ with an operculum, but $19(13.47 \%)$ produced this in the laboratory and only 2 $(1.41 \%)$ exposed presented it when sampled -1 in dormancy and 1 in segmentation; NONE with particles + operculum. For these polyps the operculum had been correlated with segmentation.

Examining Table 3, the stephanoscyphistomae which showed expected aspects of the biology of $N$. aurea, we notice: $38(29.92 \%)$ with particles inside the tube - 14 (11.02\%) exposed and 24 (18.89\%) buried; 30 (23.62\%)with an operculum, although $21(16.53 \%)$ produced this in the laboratory and only $9(7.08 \%)$ presented it when sampled; only $4(3.15 \%)$ with particles + operculum. For all these polyps, the operculum had been correlated with strobilation. Among the polyps that showed novel aspects for the biology of $N$. aurea, we noticed: 8 (6.29\%) with particles -5 in dormancy ( 1 exposed and 4 buried) and 3 buried in segmentation; $16(12.59 \%)$ with an operculum, although $10(7.87 \%)$ produced in the laboratory and $6(4.72 \%)$ presented it when sampled ( 2 exposed and 4 buried) -3 in dormancy and 3 in segmentation; NONE with particles + operculum. For these polyps the operculum had been correlated with segmentation.

\section{Discussion}

The fact that between $1 / 4-1 / 3$ of all the stephanoscyphistomae under observation had oral discs and mesenteries suggests that in nature the condition of feeding polyps must prevail against every other described situations respectively at any time. All polyps were cultivated under controlled homogeneous conditions and subjected to the same feeding regime, a favorable condition to induce strobilation for Nausithoe aurea. Nevertheless, we believe that the amount and the quality of food given to the stephanoscyphistomae did not reach a sufficient level to induce massive strobilation, even if this had far exceeded available food in nature. Werner (1979) had anticipated that for solitary coronates the surplus of energy stored by the polyps results in consecutive strobilation if there is not an annual regulation of species in waters with a high summerwinter range of temperature. Additionally, Morandini (1999) observed that cultivating 23 stephanoscyphistomae for 92 days, fed at $48 \mathrm{~h}$ intervals with the homogenate of the gonad of the clam Perna perna (Linnaeus, 1767), 22 of them strobilated and 1 remained in the normal feeding condition; 17 stephanoscyphistomae strobilated during the first 25 days of cultivation; 3,11 and 8 polyps strobilated, respectively, three, two and one time.

Survivorship of individual polyps of $N$. aurea over one year is the first record for any Coronatae polyp in na- ture. The scyphistomae of Coronatae are known to show perennation under laboratory conditions (see Ortiz-Corp's et al., 1987; Jarms, 1997; Silveira \& Morandini, 1998a). The longest documented period of survival in the laboratory is 37 years(Atorella vanhoeffeni), the stephanoscyphistoma still being alive and strobilating regularly (Jarms pers. obser. following initial culture observations by the late Dr. B. Werner). We think that stephanoscyphistomae, like the other polyps of Scyphozoa, are potentially immortal. Nevertheless, we observed that the fast growth of two encrusting organisms - sponge and coralline algae, resulted in death of some stephanoscyphistomae. We believe it to have been just by chance the time in which we made these combined observations and consider them separate events. Nevertheless, we believe that in environments with a high abundance of overgrowing or encrusting species, at least, solitary polyps cannot survive. This restricts the habitats also of $N$. aurea. In laboratory, without other animals or plants in the cultures, polyps of coronates grow continuously and there is no genetically defined maximum length. They only die if they are not able to reach a certain height in the tube after strobilation to get enough food, this being mostly the rim of the tube.

For the scyphistomae that showed expected aspects for the biology of the species we notice, comparatively, for the control and experimental series (deducing from Tables 2 and 3) that: 1) polyp tubes with particles occurred in higher frequency among the experimental series $(29.92 \%)$ in relation to the control series (16.31\%) and, for both, among the buried scyphistomae. We assume a greater probability for particles to occur inside the tubes of buried scyphistomae. Thus, in the experimental series the exposed scyphistomae are more likely to have particles inside their tubes; 2) scyphistomae with operculum occurred in higher frequency among the control series $(36.17 \%)$ in relation to the experimental series $(23.62 \%)$, but for both and in relative proportions $(72.54 \% \times 70 \%)$ the operculum was produced in the laboratory and during strobilation; 3 ) scyphistomae with particles + operculum occurred in small numbers in both series. Therefore, it is suggested that the production of the operculum is under the control of the intrinsic regulative mechanism that causes strobilation, mainly the surplus of food.

For the scyphistomae that showed novel aspects for the biology of the species, i.e. dormancy and segmentation, we notice, comparatively, for the control and experimental series (deducing from Tables 2 and 3) that: 1) polyp tubes with particles occurred in higher frequency among the $e x$ perimental series $(6.29 \%)$, mainly buried polyps, in relation to the control series (1.41\%), a likely feature as discussed above. In the control series, dormancy occurred either among buried as well as exposed polyps, 1:1. In the experimental series, we observed that dormancy and segmentation occurred, respectively, for 4 and 3 buried stephanoscyphistomae, while only 1 exposed polyp showed 
dormancy. We believe that these findings suggest that these phenomena are more likely to happen among buried scyphistomae; 2) stephanoscyphistomae with operculum occurred in slightest higher frequency among the control series (14.89\%) in relation to the experimental series (12.59\%), but for both, they occurred in the laboratory in higher relative proportions among the control series compared with the experimental series $(90.47 \%$ x $62.5 \%)$. We observed that for the control series the production of the operculum in the laboratory has always been correlated with segmentation in 9 exposed and 10 buried scyphistomae, a close ratio of 1:1 operculated polyps just sampled, respectively, in dormancy and segmentation. We observed that for the experimental series the production of the operculum in the laboratory has always been correlated with segmentation in 7 exposed and 3 buried scyphistomae, a close ratio of some 2:1 polyps just sampled, respectively, in segmentation (1 exposed and 2 buried polyps) and dormancy (1 exposed and 2 buried polyps); 3) We did not observe any polyp with particles + operculum in segmentation or dormancy. In this series the production of an operculum is related to segmentation and dormancy. So this again suggests that segmentation must be derived from normal strobilation.

The description of the reduced metagenesis, caused by unfavorable conditions in the planktonic stage in some species of the Nausithoidae (Jarms, 1997), gave rise to the idea that coronates in general have the capacity to save all living tissue, and transform it to the energy saving sessile stage - the polyp. Observations that polyps can survive up to three years without food, but under the cover of a periderm operculum, enforce this hypothesis (Jarms unpubl. data). The results of this paper strongly support this concept. Obviously, $N$. aurea is able to react with transformation of the phenotype if ecological impacts do so require. Regulation mechanisms are still unknown.

Silveira \& Morandini (1998a) defined segmentation in Linuche unguiculata as a mechanism leading to rejuvenation of the polyps and production of planuloids. The segmentation observed for $N$. aurea is similar, and is also a further argument to support planuloid formation as an explanation for polyp-stage philopatry (Silveira \& Morandini, 1997). The differences noticed are inpart due to the further development of planuloids. Distinct mobile planuloids have been seen inside the gastrovascular cavity of feeding scyphistomae of L. unguiculata, but there was no evidence that they were re-absorbed as they could easily get out (Silveira \& Morandini unpubl. data). Distinct mobile planuloids were seldom seen after segmentation in L.unguiculata, and and whenever present seemed to be dispersive stages of asexual reproduction and propagation (Silveira \& Morandini, 1998a). Often, we had observed distinct mobile planuloids inside the gastrovascular cavity of regenerating polyps of $N$. aurea, following segmentation, and these were in part entirely re-absorbed. Morandini (1999:
Tabs III-X) has noticed planuloids inside 13 scyphistomae that strobilated and produced planuloids, and that in 8 of these a few planuloids were entirely re-absorbed. Additionally, we noticed that the regenerating oral disc of the scyphistoma, after segmentation and opening of the operculum, ingests residual tissues. By inadvertent removal of the operculum, we observed a polyp of $N$. aurea beginning segmentation that quickly regenerated the oral disc, with many long tentacles, but with a very slender and stretched column. The stephanoscyphistoma started segmentation by first dividing the column in half and later producing distinct planuloids inside an operculated tube. We suggest that the transverse fission observed in the scyphistoma was determined by the incapacity of the slender column to convey food for absorption in the basal part as observed for Nausithoe planulophora and Thecoscyphus zibrowii by Bumann \& Jarms (1997).

Silveira \& Morandini (1998b) compared the transformation of polyp tissues inside two closed periderm tubes of L. unguiculata cysts, and to dormancy according to Cáceres (1997). We also compared the quiescent tissues of $N$. aurea inside closed tubes with cysts just sampled towards the end of the period of our observations. The significance of our findings goes together with the discussion in Silveira \& Morandini (1998b) that for the Scyphozoa, mainly resting stages are reported as podocysts, or, eventually, planulocysts. Nevertheless, we point out that for N. aurea, dormancy seems to be related not only with operculate polyp, but alternatively with periderm tube plugged with fine and firmed particles from the surrounding sediments.

A recent study on the evolution of Cnidaria life cycles, using data from the small sub-unit of of the ribosome to derive a phylogenetic hypothesis for "Medusozoa", suggests that Coronatae is the sister group of "semaeostomes + rhizostomes" (Collins, 2002), a probable relationship also supported by some morphological characters - the lappets, and the process of strobilation. Silveira and Morandini (1998a) have presented the hypothesis for L. unguiculata that segmentation was an advanced trait derived from a peculiar strobilation, with the addition of the operculum, although there is no operculum, either of tissue or periderm, during strobilation of the species. The observation of segmentation in an operculated strobilating species as $N$. aurea supports the idea of linking this asexual phenomenon with strobilation.

The ability of the scyphistomae of $N$. aurea, even simplified polyps in regeneration, to push particles out of their tubes, was related with their capacity of ingesting the particles. This was a direct observation that the regenerating column possesses an opening analogous with the mouth, even though the oral disc had still not differentiated. Holst (2002) has shown by experiments that $N$. aurea is able to remove $50 \%$ of sediment, stones as well as parts of mollusk shells, out of its tube after two days and and $75 \%$ after four 
days. If there are too many stones on the top of the soft body these are partly ingested. The stretching polyp pushes out the free particles, and the ingested ones are later spat out, while transported by ciliary currents. If there is too much pressure on the tube aperture from a more overlying sediment, the polyps can ingest some particles but are not able to push out either the ingested or the rest - the tube staying blocked. We believe this is the reason for shedding an operculum and undergoing dormancy.

With the results of our experiments in nature, combined with those following cultivation, we were able to show that the plasticity of the life cycle enables $N$. aurea to survive under changing conditions in the São Sebastião Channel. The trend to save all living tissue is attested by the possibility of a modification among normal metagenesis with ephyrae, the development of planuloids, and the transformation of polyp tissue by segmentation. If all these strategies fail, $N$. aurea can even undergo dormancy for a longer time.

\section{Acknowledgements}

This work was supported by Fundação de Amparo à Pesquisa do Estado de São Paulo (FAPESP 99/12433-0) and CAPES/USP PROAP/2000. ACM received financial support from FAPESP (97/03325-3, 97/08137-0 and 99/05374-7). We thank an anonymous reviewer from FAPESP for suggestions to improve the experimental design at the start of the work and for later comments on the project. We are indebted to MSc Helena Krieg Boscolo for help in the fieldwork and to Dr. Márcio Custódio (CEBIMar USP) for the identification of the sponge. We thank CEBIMar USP for providing the required facilities to obtain and examine the material throughout the work.

\section{References}

BUMANN, D. \& G. JARMS, 1997. Localization of digestion activities in polyps of Nausithoe planulophora and Thecoscyphus zibrowii (Coronatae, Scyphozoa, Cnidaria). Helgoländer Meeresunter., 51: 477-485.

CÁCERES, C.E., 1997. Dormancy in invertebrates. Invert. Biol., 116(4): 371-383.

COLLINS, A.G., 2002. Phylogeny of the Medusozoa and the evolution of cnidarian life cycles. J. Evol. Biol., 15: 418-432.

HOLST, S. 2002. Können Polypen der Coronatae (Cnidaria, Scyphozoa) Fremdkörper aus ihren Röhren entfernen? Diplomarbeit, Zoologisches Institut und Museum, Fachbereich Biologie der Universität Hamburg, Hamburg, 99p.

JARMS, G., 1990. Neubeschreibung dreier Arten der Gattung Nausithoe (Coronata, Scyphozoa) sowie
Wiederbeschreibung der Art Nausithoe marginata Kölliker, 1853. Mitt. hamb. zool. Mus. Inst., 87: 7-39.

JARMS, G., 1997. The polyps of Coronatae (Scyphozoa), a review and some new results. In: den HARTOG, J.C. (ed.), Proceedings of the $6^{\text {th }}$ International Conference on Coelenterate Biology 1995. Nationaal Natuurhistorisch Museum, Leiden, p. 271-278.

JARMS, G., 2001. The life cycle of Nausithoe hagenbecki sp. nov. (Scyphozoa, Coronatae). Mitt. hamb. zool. Mus. Inst., 98: 13-22.

JARMS, G.; U. BÅMSTEDT; H. TIEMANN; M.B. MARTINUSSEN \& J.H. FOSSA, 1999. The holopelagic life cycle of the deep-sea medusa Periphylla periphylla (Scyphozoa, Coronatae). Sarsia, 84: 55-65.

JARMS, G.; A.C. MORANDINI \& F.L. da SILVEIRA, 2002. Polyps of the families Atorellidae and Nausithoidae (Scyphozoa: Coronatae). Biota Neotropica, 2(1): 11p.

KAWAGUTI, S. \& A. MATSUNO, 1981. A new species of the Coronatae, Scyphozoa, from the Japan sea; Atorella japonica n. sp. Bull. Kawasaki Parmed. Coll., 1: 15-21.

KOMAI, T., 1936 On another form of Stephanoscyphus found in the waters of Japan. Mem. Coll. Sci. Kyoto (Ser. B), 11(3): 175-83.

MORANDINI, A.C., 1999. Gametogênese e desenvolvimento embrionário de Nausithoe aurea (Scyphozoa, Coronatae) do Canal de São Sebastião $\underline{\text { SP. MSc Dissertation, Instituto de Biociências, }}$ Universidade de São Paulo. i-iv, $136 \mathrm{p}$.

MORANDINI, A.C. \& F.L. da SILVEIRA, 2001a. New observations and new record of Nausithoe aurea (Scyphozoa, Coronatae). Pap. Av. Zool., 41(27): 519527.

MORANDINI, A.C. \& F.L. da SILVEIRA, 2001b. Sexual reproduction of Nausithoe aurea (Scyphozoa, Coronatae). Gametogenesis, egg release, embryonic development, and gastrulation. Sci. Mar., 65(2): 139149 .

ORTIZ-CORP'S, E.; C.E.CUTRESS \& B.M.CUTRESS, 1987. Life history of the coronate scyphozoan Linuche unguiculata (

KOMAI, T., 1936 On another form of Stephanoscyphus found in the waters of Japan. Mem. Coll. Sci. Kyoto (Ser. B), 11(3): 175-83.

MORANDINI, A.C., 1999. Gametogênese e desenvolvimento embrionário de Nausithoe aurea (Scyphozoa, Coronatae) do Canal de São Sebastião $\underline{\text { SP. MSc Dissertation, Instituto de Biociências, }}$ Universidade de São Paulo. i-iv, 136p.

MORANDINI, A.C. \& F.L. da SILVEIRA, 2001a. New observations and new record of Nausithoe aurea (Scyphozoa, Coronatae). Pap. Av. Zool., 41(27): 519527

http://www.biotaneotropica.org.br 
MORANDINI, A.C. \& F.L. da SILVEIRA, 2001b. Sexual reproduction of Nausithoe aurea (Scyphozoa, Coronatae). Gametogenesis, egg release, embryonic development, and gastrulation. Sci. Mar., 65(2): 139-149.

ORTIZ-CORP'S, E.; C.E. CUTRESS \& B.M. CUTRESS, 1987. Life history of the coronate scyphozoan Linuche unguiculata (Swartz, 1788). Carib. Jour. Sci., 23: 432-443.

SILVEIRA, F.L. da. \& A.C. MORANDINI, 1997. Nausithoe aurea n. sp. (Scyphozoa: Coronatae: Nausithoidae), a species with two pathways of reproduction after strobilation: sexual and asexual. Cont. Zool., 66(4): 235-246.

SILVEIRA, F.L. da. \& A.C. MORANDINI, 1998a. Asexual reproduction in Linuche unguiculata (Swartz, 1788) (Scyphozoa: Coronatae) by planuloid formation through strobilation and segmentation. Proc. biol. Soc. Wash., 111(4): 781-794.

SILVEIRA, F.L. da. \& A.C. MORANDINI, 1998b. New observations on dormancy mechanisms in Linuche unguiculata (Swartz, 1788) (Scyphozoa: Coronatae). Bol. Mus. Nac., N.S., Zool., 393: 1-7.

SÖTJE, I. \& G. JARMS, 1999. Description of Thecoscyphus zibrowii Werner, 1984 (Scyphozoa, Coronatae) with remarks on the ontogeny. Mitt. Hamb. Zool. Mus. Inst., 96:5-13.

WERNER, B. 1966. Stephanoscyphus (Scyphozoa, Coronatae) und seine direkte Abstammung von den fossilen Conulata. Helgoländer wiss. Meeresunters., 13: 317-347.

WERNER, B., 1971. Stephanoscyphus planulophorus n.spec., eine neuer Scyphopolyp mit einem neun Entwichlungsmodus. Helgoländer wiss. Meeresunters., 22: $120-140$.

WERNER, B., 1973. New investigations on systematics and evolution of the class Scyphozoa and the Phylum Cnidaria. Publs Seto mar. biol. Lab., 20: 35-61.

WERNER, B. 1974. Stephanoscyphus eumedusoides n. sp. (Syphozoa, Coronatae), ein Höhlenpolyp mit einem neuen Entwicklungsmodus. Helgoländer wiss.Meeresunters., 26: 434-463.

WERNER, B. 1979. Coloniality in the Scyphozoa: Cnidaria. In: LARWOOD, G. \& B.R. ROSEN (eds.), Biology and systematics of colonial organisms. Academic Press, London, p. 81-103.
Title: Experiments in nature and laboratory observations with Nausithoe aurea ( SCYPHOZOA: CORONATAE) support the concept of perennation by tissue saving and confirm dormancy

Authors: Fábio Lang da Silveira, Gerhard Jarms, André Carrara Morandini

Biota Neotropica, Vol. 2 (number 2): 2003

http://www.biotaneotropica.org.br/v2n $2 / \mathrm{pt} /$ a b s tract ? a r tic 1 e + B N 02202022002

Date Received 07/19/2002 - Revised 09/23/2002

Accepted 10/02/2002

ISSN 1676-0611 